\title{
Desalination of Groundwater and Impoundments using Nano-Zero Valent Iron, $\mathrm{n}-\mathrm{Fe}^{0}$
}

\author{
David D.J. Antia \\ DCA Consultants Ltd., Haughend Farm, Bridge of Earn Road, Dunning PH2 9BX, United Kingdom, e-mail: \\ dcacl@btconnect.com
}

\begin{abstract}
Salinization of groundwater is a major problem, particularly in areas with limited infrastructure. 14 diffusion reactors are operated diabatically at $-8^{\circ} \mathrm{C}$ to $20^{\circ} \mathrm{C}$ to determine the amount of $\mathrm{NaCl}$ removed by n- $\mathrm{Fe}^{0}$. The reactors establish $\mathrm{NaCl}$ removal by $\mathrm{Fe}^{0}$ : (i) 44,000-77,000 nm particle size (PS) $=0.0675-0.1925 \mathrm{~g} \mathrm{~L}^{-1}$ [feed water (FW) $\left.=0.89 \mathrm{~g} \mathrm{~L}^{-1}\right]$; (ii) $50 \mathrm{~nm} \mathrm{PS}=0.953-1.14 \mathrm{~g} \mathrm{~L}^{-1}\left[\mathrm{FW}=1.095-1.19 \mathrm{~g} \mathrm{~L}^{-1}\right]$; (iii) $50 \mathrm{~nm}$ PS under nitrogen saturation (0.1$0.2 \mathrm{MPa})=9.693 \mathrm{~g} \mathrm{~L}^{-1}\left[\mathrm{FW}=10 \mathrm{~g} \mathrm{~L}^{-1}\right]$; (iv) $<0.01 \mathrm{~g} 50 \mathrm{~nm} \mathrm{PS} \mathrm{L} \mathrm{L}^{-1}$ under nitrogen saturation $(0.1-0.2 \mathrm{MPa})=1.564 \mathrm{~g} \mathrm{~L}^{-1}$ $\left[\mathrm{FW}=4 \mathrm{~g} \mathrm{~L}^{-1}\right]$; (v) $50 \mathrm{~nm}$ PS modified by nitrogen saturation $(\mathrm{PSN})=5.52 \mathrm{~g} \mathrm{~L}^{-1}\left[\mathrm{FW}=6.89 \mathrm{~g} \mathrm{~L}^{-1}\right]$. Desalination commences at a time, $\mathrm{t}$, after the $\mathrm{n}-\mathrm{Fe}^{0}$ is added to the water, and continues with an exponential decline until a base (equilibrium) salinity is reached. The effectiveness of $n-\mathrm{Fe}^{0}$ as a desalination agent appears to increase with increased water salinity. Placement of PSN in an existing impoundment, or aquifer, may provide a cost effective, zero energy, partial desalination solution, which can be used to support emergency relief, agriculture and extractive industries.
\end{abstract}

Keywords: desalination, Zero valent Iron (ZVI), diffusion, saline aquifers, saline impoundments

Submitted 16 November 2014, revised 13 April 2015, accepted 29 April 2015

\section{Introduction}

Salinization of ground water by irrigation, infiltration and contamination of groundwater by the disposal of water in saline impoundments (e.g. flowback water, water associated with hydrocarbon production and tailing ponds associated with mining) are increasingly being considered as adverse environmental impacts of riparian discharge by agriculture and extractive industries (e.g. shale gas, shale oil) (e.g. Hill, Koenig 1999; Grattan 2002; Katerji et al. 2003; El-Nashar 2013; Rahil et al. 2013; Rasel et al. 2013; Pandey 2013; Warner et al. 2013; Vengosh et al. 2014; Yu et al. 2014; Yurtseven et al. 2014). Salinized ground water and irrigation water is found in all continents and represents $10-40 \%$ of global arable land (Knapp, Baerenklau 2006; FAO, 2011; Panta et al. 2014).

Desalination of riparian water, groundwater and impoundments, is energy intensive, has a high capital requirement, and has comparatively high operating costs (\$0.2$15 \mathrm{~m}^{3}$ ) (e.g. Raluy et al. 2004; Elimelech, Phillip 2011; Zotalis et al. 2014). A separated waste portion of the product water $(5-70 \%)$ is a hypersaline brine (reject brine) (e.g. Hajbl et al. 2010; Balasubramanian 2013). Large scale desalination plants (greater than $100,000 \mathrm{~m}^{3} \mathrm{~d}^{-1}$ ) may be able to desalinize water for less than $\$ 3 \mathrm{~m}^{-3}$ (Al Hashemi et al. 2014; Sorour et al. 2014; Venkatesan 2014). The principal commercial technologies are reverse osmosis (RO) and multistage flash distillation (MSFD) (e.g. Raluy et al. 2004; Younos, Tulou 2005; Elimelech, Phillip 2011).
Most sites requiring desalination (for irrigation, livestock, or for the disposal of saline water into the environment (e.g. ground water, an aquifer, lacustrine environment, or riparian system)) contain a relatively small amount of saline water, e.g. less than $10-100,000 \mathrm{~m}^{3}$. They do not have ready access to energy, or infrastructure, and require the desalination to be undertaken for a cost of less than $\$ 600 \mathrm{~m}^{-3}$ to be economically viable (e.g. Butler et al. 2013; Al Hashemi et al. 2014; Boschee 2014; Zekri et al. 2014). In many cases the site owners do not have access to the substantial capital, regional infrastructure, or energy infrastructure, required to install a RO or MSFD desalination plant.

This study provides the first evidence (using 14 diffusion reactors) that saline impoundments and groundwater contained in salinized aquifers (or saline irrigation water, or saline impoundments) can be desalinated at atmospheric temperatures and pressures of 0.09-0.2 MPa using nanoZero Valent Metal (n-ZVM). ZVM includes zero valent iron (ZVI, $\left.\mathrm{Fe}^{0}\right)$, zero valent aluminium $\left(\mathrm{Al}^{0}\right)$, and zero valent copper $\left(\mathrm{Cu}^{0}\right)$.

The n-ZVM (or nitrogen modified n-ZVM) is either injected into the aquifer, or placed in the impoundment, or placed in a salinized water body. This partial desalination approach requires no external energy, no infrastructure, no capital investment (if the impoundment or tank already exists) and has no operating costs (beyond placing the $\mathrm{n}-\mathrm{ZVM}$ in the water, and removing the product water). Desalination at 0.1-0.2 MPa under a nitrogen atmosphere re- 
quires a pressured nitrogen source and a low pressure (0.1-0.2 MPa) sealed reactor shell.

$\mathrm{n}-\mathrm{Fe}^{0}$ reacts (corrodes) in the presence of water (i.e. $\mathrm{Fe}^{0}=\mathrm{Fe}^{\mathrm{n}+}+\mathrm{ne}^{-} ; \mathrm{nH}_{2} \mathrm{O}=\mathrm{nH}^{+}$(ads) $+\mathrm{nOH}^{-}($ads $) ; \mathrm{n}$ is 1 , 2, 3, or 4 (typically 2 or 3) (Pourbaix 1974; Antia 2014). Initially the adsorbed $\mathrm{H}^{+}$is removed by the reaction $\left(4 \mathrm{H}^{+}(\mathrm{ads})+4 \mathrm{e}^{-}+\mathrm{O}_{2}(\mathrm{aq})=2 \mathrm{H}_{2} \mathrm{O}\right)$. Water saturated with an inert gas (e.g. Ar, $\mathrm{He}, \mathrm{N}, \mathrm{Ne}, \mathrm{Kr}, \mathrm{Xe}$ ), becomes depleted in $\mathrm{O}_{2}$. At this point the concentration of adsorbed $\mathrm{H}^{+}$on the n-Fe ${ }^{0}$ starts to increase. Excess $\mathrm{H}^{+}$is removed as $\mathrm{H}_{2}$ (gas), i.e. $2 \mathrm{H}^{+}$(ads) $+2 \mathrm{e}^{-}=\mathrm{H}_{2}$ (g) (Pourbaix 1974; Antia 2014).

\subsection{Background}

Water analyses either side of ZVM permeable reactive barriers (PRB's) have observed decreases in the concentration of $\mathrm{Na}^{+}$and $\mathrm{Cl}^{-}$ions in the product water from $101 \mathrm{mg} \mathrm{L}^{-1}$ to $54 \mathrm{mg} \mathrm{L}^{-1}$ (Wilkin et al. 2003). Savoie et al. (2004) discovered that $\mathrm{Cl}^{-}$ions could be preferentially removed (relative to $\mathrm{Na}^{+}$ions) by a ZVI PRB. Desalination associated with ZVM has previously been recorded in reactor studies (Antia 2010; Fronczyk et al. 2010; Fronczyk et al. 2012).

1.1.1. Reduction of the amount of salt in saline winter road runoff

Two experiments undertaken by Fronczyk et al. (2010) using ZVI and saline water established: (a) $\mathrm{Cl}^{-}$reduction from 1.52913 to $1.19831 \mathrm{~g} \mathrm{~L}^{-1}$ (temperature $=15.3^{\circ} \mathrm{C}$ ), where the $\mathrm{pH}$ changed from 6.47 to 9.59 and the electrical conductivity (EC) increased from 3.9 to $4.51 \mathrm{mScm}^{-1}$. (b) $\mathrm{Cl}^{-}$reduction from 1.52913 to $1.03522 \mathrm{~g} \mathrm{~L}^{-1}$, where $\mathrm{pH}$ changed from 8.48 to 9.68 and $\mathrm{EC}$ increased from 3.58 to $4.54 \mathrm{mScm}^{-1}$, temperature $15.4^{\circ} \mathrm{C}$. The experimental details can be interpreted as: $5 \mathrm{~g}$ ZVI powder [BET surface area $\left.=77.26 \mathrm{~m}^{2} \mathrm{~g}^{-1}\right]$ placed in $1.5 \mathrm{~L}$ water for $48 \mathrm{hrs}$. The observations are highly significant as they suggest that substantive $\mathrm{Cl}^{-}(\mathrm{NaCl})$ reduction can be associated with both a $\mathrm{pH}$ rise and an $\mathrm{EC}$ rise. $\mathrm{EC}$ can be directly linked to the water salinity: [Salinity $\left(\mathrm{g} \mathrm{L}^{-1}\right)=\mathrm{EC}\left(\mathrm{mScm}^{-1}\right) \times F$ ], where $F$ is a constant within the range $0.5-0.55$ (Misstear et al. 2006). No previous redox linkage between $\mathrm{pH}$ increase and $\mathrm{NaCl}$ removal has been identified (e.g. Pourbaix 1974).

A subsequent study using $\mathrm{HCl}$ (Fronczyk et al. 2012) was designed to examine chloride retention on ZVI over a 24 hour period. This study established a regression relationship between $\mathrm{Cl}^{-}$concentration in the feed water $\left[\mathrm{C}_{\mathrm{F}}\right]$ and product water $\left[\mathrm{C}_{\mathrm{R}}\right]$ where $\mathrm{C}_{\mathrm{R}}, \mathrm{mg} \mathrm{L}^{-1}=1.1 \mathrm{C}_{\mathrm{R}}^{0.98}\left[\mathrm{R}^{2}=\right.$ 0.99]. $\mathrm{No} \mathrm{Cl}^{-}$removal is predicted when $\mathrm{C}_{\mathrm{F}}$ is greater than
$100 \mathrm{mg} \mathrm{L}^{-1} .3 \% \mathrm{Cl}^{-}$removal is predicted for $\mathrm{C}_{\mathrm{F}}=0.5 \mathrm{~g} \mathrm{~L}^{-1}$. This rises to $9 \%$ for $\mathrm{C}_{\mathrm{F}}=10 \mathrm{~g} \mathrm{~L}^{-1}$.

\subsubsection{Reduction of the amount of salt in irrigation water}

A study (Antia 2010) using a ZVM $\left[\mathrm{Fe}^{0}\right.$ and $\mathrm{Fe}^{0}+\mathrm{Al}^{0}$ $+\mathrm{Cu}^{0}$ ]: [Ca-montmorillonite] combination established reductions in salinity of $20-45 \%$ over 100 days (from a feed water containing less than $1 \mathrm{~g} \mathrm{NaCl} \mathrm{L}^{-1}\left(\mathrm{EC}=2 \mathrm{mScm}^{-1}\right)$. The ZVM particle size was in the range 44,000$77,000 \mathrm{~nm}$. The salinity declined exponentially with time to a base level after about 40 days. $\mathrm{Fe}^{0}$ was a more effective desalination agent than $\mathrm{Fe}^{0}+\mathrm{Al}^{0}+\mathrm{Cu}^{0}$. Desalination in this media combination is principally by montmorillonite cation exchange (e.g. Charlet, Tornassat 2005; \Antia, 2010).

\section{2. $n-\mathrm{Fe}^{0}$ Desalination Mechanisms}

Placement of $\mathrm{Fe}^{0}$ in saline water will result in the formation of rust corrosion products, where the dominant corrosion product is beta-FeOOH (akaganeite) (Tang et al. 2006). $\mathrm{Cl}^{-}$ions catalyse the reaction: $\left[\mathrm{Fe}^{0}+\mathrm{nCl}^{-}=\mathrm{Fe}^{\mathrm{n}+} \mathrm{nCl}^{-}+\mathrm{ne}\right.$ and $\left.\mathrm{Fe}^{\mathrm{n}+} \mathrm{nCl}^{-}+\mathrm{ne}^{-}=\mathrm{Fe}^{\mathrm{n}+}+\mathrm{nCl}^{-}+\mathrm{ne}\right]$, and act as a phase distributor (Perez et al. 2009). As the thickness of the surface rust layer $\left(\mathrm{FeOOH}, \mathrm{mH}_{2} \mathrm{O}\right)$, surrounding the $\mathrm{n}-\mathrm{Fe}^{0}$ core, grows the $(-\mathrm{OH})$ groups on the surface of the rust change to $\left(-\mathrm{OH}_{2}\right)^{+}$groups (Perez et al. 2009). This both attracts $\mathrm{Cl}^{-}$ions and allows $\mathrm{Cl}^{-}$ions to migrate through the rust to the metal surface. The boundary between the porous, hydrated, $\mathrm{FeOOH}$ rust layer and the $\mathrm{n}-\mathrm{Fe}^{0}$ core is characterised by the presence of either a hydrated magnetite $\left(\mathrm{Fe}_{3} \mathrm{O}_{4} \cdot \mathrm{xH}_{2} \mathrm{O}\right)$ or a mixed valance green rust complex $\left(\mathrm{M}_{(\mathrm{a}=1-\mathrm{c}-\mathrm{b})}^{\mathrm{I}} \mathrm{M}_{(\mathrm{b}=1-\mathrm{c}-\mathrm{a})}^{\mathrm{II}} \mathrm{M}^{\mathrm{III}}{ }_{\mathrm{c}}(\mathrm{OH})_{2}\right]^{\mathrm{x}-} \cdot\left[(\mathrm{x} / \mathrm{n}) \mathrm{A}^{\mathrm{n}-} \cdot \mathrm{mH}_{2} \mathrm{O}\right]^{\mathrm{x+}}$, where $\mathrm{a}+\mathrm{b}+\mathrm{c}=1 ; \mathrm{M}=\operatorname{metal}($ (e.g. Fe), $\mathrm{A}=$ anodic species (e.g. Cl) (Ruby et al. 2006; Al-Moubaraki et al. 2015). The $\mathrm{FeOOH}$ can also template formation of a green rust layer at the rust-water interface (Ruby et al. 2006). This green rust grows by removing cation pollutants (e.g. Na, K, B, Ba, Ca, $\mathrm{Mg}, \mathrm{Mn}, \mathrm{Sr}$ ) and anion pollutants (e.g. $\mathrm{Cl}^{-}, \mathrm{SO}_{4}{ }^{2-}, \mathrm{CO}_{3}{ }^{2-}$ ) contained in the water (Ruby et al. 2006).

$\mathrm{FeOOH}$ attracts $\mathrm{NaCl}$ from the surrounding water to its outer hydrated shell and inner ionic layers (Yue et al. 2011). The $\mathrm{NaCl}$ concentrations within this hydrated shell can fall within the range 1-8 moles $\mathrm{NaCl} \mathrm{L}^{-1}$ (Yue et al. 2011). Proton $\left(\mathrm{H}^{+}\right)$binding and an associated ion exchange at the water interface are the principal mechanism for cation and anion adsorption (Kozin, Boily, 2013). The (100) $\mathrm{FeOOH}$ crystallite surfaces have $(-\mathrm{OH})^{-}$terminal sites, while the $(010) \mathrm{FeOOH}$ crystallite surfaces have $\left(-\mathrm{OH}_{2}\right)^{+}$ terminal sites (Otte et al. 2012). The potential desalination 
mechanisms associated with $\mathrm{n}-\mathrm{Fe}^{0}$ are: (a) adsorption at the terminal sites as (i) $\left.\left(\left(-\mathrm{OH}_{2}\right)^{+}\right)\left(\mathrm{Cl}^{-}\right)\right)$and (ii) $\left((-\mathrm{OH})^{-}\right)$ $\left(\mathrm{Na}^{+}\right)$), and (b) incorporation into green rusts accreting around $\mathrm{n}-\mathrm{Fe}^{0}$ particles.

\section{Methodology}

This study uses 14 diffusion reactors to determine whether ZVM desalination is a function of particle size, ZVM composition, and whether the rate of desalination can be enhanced by nitrogen pre-treatment. The function of each reactor is summarised in Table 1 .

\section{1. n-ZVM Control Tests: Particle Size: $44,000-77,000$ $\mathrm{nm}$; Surface Area $=0.00289-0.01732 \mathrm{~m}^{2} \mathrm{~g}^{-1}$}

0.3 L MDPE reactors containing either fresh water (Reactors 1, 2, 3), or saline water (Reactors 4, 5) were used to provide a reference data set. The saline water was manufactured by adding $\mathrm{NaCl}$ to fresh water. Three ZVM combinations (Table 2) were constructed ( $\mathrm{Fe}^{0}$ (Reactors 2, 4), $\mathrm{Fe}^{0}+\mathrm{Cu}^{0}$ (Reactor 3), $\mathrm{Fe}^{0}+\mathrm{Cu}^{0}+\mathrm{Al}^{0}$ (Reactor 1, 5). Each reactor had an air-water interface and was operated at atmospheric temperature (Fig. 1a-b) and atmospheric pressure.

Table 1. Summary of the Different Reactors

\begin{tabular}{|l|l|l|l|l|}
\hline Reactors & $\mathrm{Fe}^{0}$ Particle Size $[\mathrm{nm}]$ & Water Type & Treatment & Objective \\
\hline $1,2,3$ & $44,000-77,000$ & Fresh & None & Control data set \\
\hline 4,5 & $44,000-77,000$ & Saline & None & Control data set \\
\hline $6,7,8$ & 50 & Fresh & None & Control data set \\
\hline $9,10,11$ & 50 & Saline & None & Control data set \\
\hline $12 \mathrm{~A}$ & 50 & Saline & $\mathrm{N}_{2}$ Gas Flow & Manufacture \\
\hline $12 \mathrm{~B}$ & None & Saline & Gas Flow & Control data set \\
\hline $12 \mathrm{C}$ & None & Organic rich & Gas Flow & Control data set \\
\hline 13,14 & 50 & Saline & Pre-Treated & Benefit of $\mathrm{N}_{2}$ pre-treatment \\
\hline
\end{tabular}

Table 2. Feed Water and ZVM Details. NaCl added for Reactors 4, 5, 9-11, 13-14 is calculated as: (EC Saline Feed Water $-\mathrm{EC}$ Fresh Water before $\mathrm{NaCl}$ is added) $* \mathrm{~F}$ (Misstear et al. 2006) where $\mathrm{F}=0.5$. F can vary within the range $0.5-0.55$ (Misstear et al. 2006). $\mathrm{NaCl}$ added for Reactors $12 \mathrm{~A}$ and $12 \mathrm{~B}$ is calculated as weight of $\mathrm{NaCl}$ added $(\mathrm{g}) /$ Water volume $(\mathrm{L})$ in the reactor

\begin{tabular}{|c|c|c|c|c|c|c|c|c|c|}
\hline \multirow{3}{*}{$\begin{array}{l}\stackrel{\check{0}}{0} \\
\ddot{\mathscr{J}} \\
\check{\sim}\end{array}$} & \multirow{2}{*}{\multicolumn{2}{|c|}{ Feed Water }} & \multirow{3}{*}{$\begin{array}{c}\mathrm{EC} \\
\mathrm{mScm}^{-1}\end{array}$} & \multirow{3}{*}{$\begin{array}{c}\begin{array}{c}\mathrm{NaCl} \\
\text { added }\end{array} \\
\mathrm{g} \mathrm{L}^{-1}\end{array}$} & \multirow{3}{*}{$\begin{array}{c}50 \mathrm{~nm} \\
\mathrm{Fe}^{0} \\
\mathrm{M} \mathrm{L}^{-1}\end{array}$} & \multicolumn{2}{|c|}{$44,000-77,000 \mathrm{~nm}$} & \multirow{3}{*}{$\frac{\mathrm{Cu}^{0}}{\mathrm{M} \mathrm{L}^{-1}}$} & \multirow{3}{*}{$\frac{\mathrm{ZVM}}{\mathrm{g} \mathrm{L}^{-1}}$} \\
\hline & & & & & & \multirow{2}{*}{$\frac{\mathrm{Fe}^{0}}{\mathrm{M} \mathrm{L}^{-1}}$} & \multirow{2}{*}{$\frac{\mathrm{Al}^{0}}{\mathrm{M} \mathrm{L}^{-1}}$} & & \\
\hline & Eh, V & $\mathrm{pH}$ & & & & & & & \\
\hline 1 & 0.03 & 7.12 & 0.35 & 0.00 & 0.00 & 1.07 & 0.58 & 0.15 & 85.0 \\
\hline 2 & 0.03 & 7.12 & 0.35 & 0.00 & 0.00 & 1.07 & 0.0 & 0.0 & 60.0 \\
\hline 3 & 0.03 & 7.12 & 0.35 & 0.00 & 0.00 & 1.07 & 0.0 & 0.15 & 69.3 \\
\hline 4 & 0.11 & 7.50 & 2.03 & 0.84 & 0.00 & 1.07 & 0.0 & 0.0 & 60.0 \\
\hline 5 & 0.11 & 8.20 & 2.13 & 0.89 & 0.00 & 1.07 & 0.58 & 0.15 & 85.0 \\
\hline 6 & 0.10 & 7.06 & 0.27 & 0.00 & 0.30 & 0.00 & 0.00 & 0.0 & 16.7 \\
\hline 7 & 0.10 & 7.06 & 0.27 & 0.00 & 0.30 & 0.00 & 0.00 & 0.26 & 33.3 \\
\hline 8 & 0.10 & 7.06 & 0.27 & 0.00 & 0.30 & 0.00 & 0.62 & 0.26 & 50.0 \\
\hline 9 & 0.04 & 7.32 & 2.43 & 1.095 & 0.30 & 0.00 & 0.00 & 0.00 & 16.7 \\
\hline 10 & 0.04 & 7.32 & 2.43 & 1.095 & 0.30 & 0.00 & 0.00 & 0.26 & 33.3 \\
\hline 11 & 0.04 & 7.32 & 2.43 & 1.095 & 0.30 & 0.00 & 0.62 & 0.26 & 50.0 \\
\hline $12 \mathrm{~A}$ & 0.09 & 7.21 & 0.39 & 10.00 & 0.49 & 0.00 & 1.01 & 0.21 & 68.2 \\
\hline $12 \mathrm{~B}$ & 0.11 & 7.13 & 8.00 & 4.00 & 0.00 & 0.00 & 0.00 & 0.00 & 0.0 \\
\hline $12 \mathrm{C}$ & 0.06 & 4.04 & 1.43 & 0.00 & 0.00 & 0.00 & 0.00 & 0.00 & 0.0 \\
\hline 13 & -0.09 & 8.90 & 18.33 & 9.03 & 0.00 & 0.00 & 0.00 & 0.00 & 0.7 \\
\hline 14 & 0.04 & 8.96 & 14.05 & 6.89 & 0.00 & 0.00 & 0.00 & 0.00 & 1.7 \\
\hline
\end{tabular}


2.2. n-ZVM Particle Size Reduction Tests: Particle Size: $50 \mathrm{~nm}$ : Surface Area $=20 \mathrm{~m}^{2} \mathrm{~g}^{-1}$

0.3 L MDPE reactors containing either fresh water (Reactors 6-8), or saline water (Reactors 9-11) were used to determine if reducing particle size and increasing surface area increased the rate of desalination. The saline water was manufactured by adding $\mathrm{NaCl}$ to fresh water. Three ZVM combinations (Table 2) were constructed $\left(\mathrm{Fe}^{0}\right.$ (Reactors 6, 9), $\mathrm{Fe}^{0}+\mathrm{Cu}^{0}$ (Reactor 7, 10), $\mathrm{Fe}^{0}+\mathrm{Cu}^{0}+\mathrm{Al}^{0}$ (Reactor 8, 11)). Each reactor had an air-water interface and was operated at atmospheric temperature and pressure (Fig. 1c-d).

2.3. n-ZVM Impact of $N_{2}$ Saturation: Particle Size: $50 \mathrm{~nm}$ : Surface Area $=20 \mathrm{~m}^{2} \mathrm{~g}^{-1}$

Three sealed $\mathrm{Cu}^{0}$ reactors (12A, 12B and 12C) were constructed. Nitrogen gas was bubbled through Reactor $12 \mathrm{~A}$ and the product gas from Reactor $12 \mathrm{~A}$ was bubbled through Reactor 12B. The product gas from Reactor 12B was then bubbled through Reactor 12C. Reactor 12A contained 1.1 L fresh water $+\mathrm{n}-\mathrm{Fe}^{0}(50 \mathrm{~nm})+\mathrm{Cu}^{0}(44,000$ $77,000 \mathrm{~nm})+\mathrm{Al}^{0}(44,000-77,000 \mathrm{~nm})($ Table 2). $\mathrm{NaCl}$ was added to Reactor $12 \mathrm{~A}$ at the times noted in Fig. 6d. Reactor $12 \mathrm{~B}$ contained $1.4 \mathrm{~L}$ of saline water (and no $\mathrm{ZVM}$ ). Reactor $12 \mathrm{C}$ contained $0.4 \mathrm{~L}$ of a mixture of carboxylic acids and phenols (and no ZVM). The partial pressure of the Reactor $12 \mathrm{~A}$ was maintained at between 0.1 and $0.2 \mathrm{MPa}$ by nitrogen gas. The nitrogen gas flow rate was $30 \mathrm{~mL}^{\text {minute }}{ }^{-1}$. Each reactor contained a $1.5 \mathrm{~m}$ water column above the gas distributor. Makeup water was added when the water column height fell to $1.25 \mathrm{~m}$. Each reactor had a nitrogen (or $\mathrm{N}_{2}+\mathrm{H}_{2}$ ) - water interface and was operated at atmospheric temperature (Fig. 6j).

2.4. Reuse of $n-Z V M$ modified by $\mathrm{N}_{2}$ Saturation: Particle Size: $50 \mathrm{~nm}$ : Surface Area $=20 \mathrm{~m}^{2} \mathrm{~g}^{-1}$

Part of the product ZVM from Reactor 12A (Table 2) was placed in two 0.3 L MDPE reactors (Reactors 13 and 14) to determine if modification of $Z V M$ by $N_{2}$ saturation enhanced the $\mathrm{NaCl}$ removal properties of $\mathrm{n}-\mathrm{Fe}^{0}$. Each reactor had an air-water interface and was operated at atmospheric temperature and pressure (Fig. 1c-d).

\subsection{Measurement Equipment}

Eh, pH, Temperature, EC (electrical conductivity) measurements were made using instruments manufactured by Hanna, Oakton, and Extech. Calibration fluids were manufactured by Hanna. The calibration methodology used to define Eh is described in Jardim (2014). Gas chromatograph analyses (Reactor 12) were undertaken using a SRI 8610C TCD GC with a silica gel column and a helium carrier gas (manufactured by BOC/Linde). The heating program and temperature of operation was designed to allow quantification of $\mathrm{H}_{2}, \mathrm{~N}_{2}$ and $\mathrm{CO}_{2}$, i.e. Initial $15-20^{\circ} \mathrm{C}$ held for 1 minute followed by a $20^{\circ} \mathrm{C} \mathrm{min}{ }^{-1}$ temperature ramp for 15 minutes. The calibration gas standards $\left(\mathrm{H}_{2}\right.$, $\mathrm{N}_{2}, \mathrm{CO}_{2}$ ) used were manufactured by BOC/Linde. Cation and anion analyses (Reactors $12 \mathrm{~A}, 12 \mathrm{~B}$, and 14) were contracted to Forest Research (the commercial laboratories of the UK Forestry Commission). The water samples were passed through a $450 \mathrm{~nm}$ filter prior to analysis. Anions were analysed using Dionex ion chromatography. Cations were analysed using a Thermo Icap 6500 spectrometer.

\subsection{Materials}

The $\mathrm{n}-\mathrm{Fe}^{0}$ (50 nm, Nanofer Star) was provided by Nano Iron s.r.o. The $\mathrm{Fe}^{0}+\mathrm{Cu}^{0}+\mathrm{Al}^{0}(44,000-77,000 \mathrm{~nm})$ and $\mathrm{NaCl}$ was purchased from UK commercial suppliers. The 44,000-77,000 nm ZVM powders are illustrated in Antia (2010). The $\mathrm{N}_{2}$ and He gases used were purchased from $\mathrm{BOC} /$ Linde.

\section{Results}

Fig. 1-7 contains the recorded temperature, $\mathrm{pH}, \mathrm{Eh}$, EC, salinity and gas composition data associated with each reactor: (i) Temperature and pressure (Fig. 1); (ii) Reactors 1-3 (Fig. 2); (ii) Reactors 4, 5 (Fig. 3); (iii) Reactors 6-8 (Fig. 4); (iv) Reactors 9-11 (Fig. 5); (v) Reactors 12A, 12B, 12C (Fig. 6); and (vi) Reactors 13, 14 (Fig. 7). Tables 2, 3 contains: (i) the feed water details (Eh, $\mathrm{pH}, \mathrm{EC}$, salinity) for each reactor (Table 2); (ii) the ZVM composition and concentration details for each reactor (Table 2) and (iii) the feed water and product water anion and cation analyses for Reactors 12A, 12B and 14 (Table 3).

\subsection{Control Reactors Containing Fresh Water (Reac- tors 1-3, 6-8)}

Reactors 1-3 (Fig. 2a-d) and Reactors 6-8 (Fig. $5 \mathrm{a}-\mathrm{d})$ demonstrate that the relative changes in water $\mathrm{Eh}, \mathrm{pH}$ and EC are similar for ZVM with a $50 \mathrm{~nm}$ and a $(44,000$ $77,000 \mathrm{~nm}$ ) particle size.

\subsection{Control Reactors Containing Saline Water (Reac-} tors $4,5,9-11$ ) 
Table 3 Anion and Cation Analyses, Reactors 12A, 12B, 14

\begin{tabular}{|c|c|c|c|c|c|c|c|}
\hline \multicolumn{8}{|l|}{ Anions } \\
\hline \multirow{2}{*}{ Reactor } & & $\mathrm{Cl}$ & $\mathrm{NO}_{3}$ & $\mathrm{SO}_{4}$ & $\mathrm{PO}_{4}$ & $\mathrm{~F}$ & $\mathrm{NO}_{2}$ \\
\hline & & $\mathrm{mg} \mathrm{L}^{-1}$ & $\mathrm{mg} \mathrm{L}^{-1}$ & $\mathrm{mg} \mathrm{L}^{-1}$ & $\mathrm{mg} \mathrm{L}^{-1}$ & $\mathrm{mg} \mathrm{L}^{-1}$ & $\mathrm{mg} \mathrm{L}^{-1}$ \\
\hline \multirow{3}{*}{$12 \mathrm{~A}$} & Feed & 6150.70 & 80.60 & 29.69 & $<0.1$ & 0.17 & 0.26 \\
\hline & Product & 269.89 & 0.31 & 3.30 & $<0.1$ & 0.04 & 0.05 \\
\hline & Removed & 5880.81 & 80.29 & 26.39 & & 0.13 & 0.22 \\
\hline \multirow{3}{*}{$12 \mathrm{~B}$} & Feed & 2510.33 & 80.60 & 29.69 & $<0.1$ & 0.17 & 0.26 \\
\hline & Product & 1612.70 & 0.82 & 4.76 & $<0.1$ & 0.02 & 2.34 \\
\hline & Removed & 897.63 & 79.78 & 24.92 & & 0.15 & -2.08 \\
\hline \multirow{3}{*}{14} & Feed & 4568.84 & 11.28 & 4.16 & $<0.1$ & 0.02 & 0.04 \\
\hline & Product & 648.83 & 4.34 & 1.78 & $<0.1$ & $<0.02$ & 1.32 \\
\hline & Removed & 3920.01 & 6.94 & 2.37 & & & -1.28 \\
\hline
\end{tabular}

B. Cations, $\mathrm{K}, \mathrm{Ca}, \mathrm{Mg}, \mathrm{Na}, \mathrm{Al}, \mathrm{Fe}, \mathrm{Mn}$

\begin{tabular}{|c|c|c|c|c|c|c|c|c|}
\hline \multirow{2}{*}{ Reactor } & & K & $\mathrm{Ca}$ & $\mathrm{Mg}$ & $\mathrm{Na}$ & $\mathrm{Al}$ & $\mathrm{Fe}$ & $\mathrm{Mn}$ \\
\hline & & $\mathrm{mg} \mathrm{L}^{-1}$ & $\mathrm{mg} \mathrm{L}^{-1}$ & $\mathrm{mg} \mathrm{L}^{-1}$ & $\mathrm{mg} \mathrm{L}^{-1}$ & $\mathrm{mg} \mathrm{L}^{-1}$ & $\mathrm{mg} \mathrm{L}^{-1}$ & $\mathrm{mg} \mathrm{L}^{-1}$ \\
\hline \multirow{3}{*}{$12 \mathrm{~A}$} & Feed & 12.04 & 235.13 & 75.32 & 3977.83 & $<0.15$ & $<0.03$ & 0.002 \\
\hline & Product & 19.59 & 6.84 & 0.73 & 164.78 & $<0.15$ & $<0.03$ & 0.348 \\
\hline & Removed & -7.55 & 228.29 & 74.58 & 3813.05 & & & -0.346 \\
\hline \multirow{3}{*}{$12 \mathrm{~B}$} & Feed & 12.04 & 235.13 & 75.32 & 1681.82 & $<0.15$ & $<0.03$ & 0.002 \\
\hline & Product & 17.98 & 18.70 & 5.23 & 1014.56 & $<0.15$ & 0.04 & 0.068 \\
\hline & Removed & -5.94 & 216.43 & 70.08 & 667.26 & & -0.01 & -0.067 \\
\hline \multirow{3}{*}{14} & Feed & 1.69 & 32.91 & 10.54 & 3039.15 & $<0.15$ & $<0.03$ & 0.002 \\
\hline & Product & 6.30 & 13.85 & 4.35 & 412.63 & $<0.15$ & $<0.03$ & 0.088 \\
\hline & Removed & -4.61 & 19.06 & 6.20 & 2626.52 & & & -0.086 \\
\hline
\end{tabular}

C. Cations, P, S, B, Ba, Cd, Co, Cr

\begin{tabular}{|c|c|c|c|c|c|c|c|c|}
\hline \multirow{2}{*}{ Reactor } & & $\mathrm{P}$ & $\mathrm{S}$ & B & $\mathrm{Ba}$ & $\mathrm{Cd}$ & Co & $\mathrm{Cr}$ \\
\hline & & $\mathrm{mg} \mathrm{L}^{-1}$ & $\mathrm{mg} \mathrm{L}^{-1}$ & $\mathrm{mg} \mathrm{L}^{-1}$ & $\mathrm{mg} \mathrm{L}^{-1}$ & $\mathrm{mg} \mathrm{L}^{-1}$ & $\mathrm{mg} \mathrm{L}^{-1}$ & $\mathrm{mg} \mathrm{L}^{-1}$ \\
\hline \multirow{3}{*}{$12 \mathrm{~A}$} & Feed & $<0.1$ & 30.80 & 0.07 & 0.969 & $<0.0002$ & $<0.0002$ & $<0.002$ \\
\hline & Product & $<0.1$ & 3.37 & 0.03 & $<0.015$ & $<0.0002$ & 0.0002 & $<0.002$ \\
\hline & Removed & & 27.43 & 0.04 & & & & \\
\hline \multirow{3}{*}{$12 \mathrm{~B}$} & Feed & $<0.1$ & 30.80 & 0.07 & 0.969 & $<0.0002$ & $<0.0002$ & $<0.002$ \\
\hline & Product & $<0.1$ & 4.75 & 0.01 & 0.126 & 0.0006 & 0.0020 & $<0.002$ \\
\hline & Removed & & 26.05 & 0.05 & 0.843 & & & \\
\hline \multirow{3}{*}{14} & Feed & $<0.005$ & 4.31 & 29.40 & 0.136 & $<0.0002$ & $<0.00020$ & $<0.002$ \\
\hline & Product & 0.003 & 1.93 & 10.34 & 0.045 & $<0.0002$ & 0.00055 & $<0.002$ \\
\hline & Removed & & 2.37 & 19.06 & 0.091 & & & \\
\hline
\end{tabular}

D. Cations, $\mathrm{Cu}, \mathrm{Ni}, \mathrm{Pb}, \mathrm{Si}, \mathrm{Sr}, \mathrm{Zn}$

\begin{tabular}{|c|l|r|r|r|r|r|r|}
\hline \multirow{3}{*}{ Reactor } & & \multicolumn{1}{c|}{$\mathrm{Cu}$} & $\mathrm{Ni}$ & \multicolumn{1}{c|}{$\mathrm{Pb}$} & \multicolumn{1}{c|}{$\mathrm{Si}$} & \multicolumn{1}{c|}{$\mathrm{Sr}$} & \multicolumn{1}{c|}{$\mathrm{Zn}$} \\
\cline { 3 - 8 } & & $\mathrm{mg} \mathrm{L}^{-1}$ & $\mathrm{mg} \mathrm{L}^{-1}$ & $\mathrm{mg} \mathrm{L}^{-1}$ & \multicolumn{1}{c|}{$\mathrm{mg} \mathrm{L}^{-1}$} & $\mathrm{mg} \mathrm{L}^{-1}$ & $\mathrm{mg} \mathrm{L}^{-1}$ \\
\hline \multirow{3}{*}{$12 \mathrm{~A}$} & Feed & 0.56 & $<0.003$ & $<0.01$ & 37.23 & 1.04 & 0.27 \\
\cline { 2 - 8 } & Product & 0.03 & $<0.003$ & $<0.01$ & 0.32 & 0.03 & 0.75 \\
\cline { 2 - 8 } & Removed & 0.53 & & & 36.91 & 1.01 & -0.48 \\
\hline \multirow{3}{*}{$12 \mathrm{~B}$} & Feed & 0.56 & $<0.003$ & $<0.01$ & 37.23 & 1.04 & 0.27 \\
\cline { 2 - 8 } & Product & 0.34 & $<0.003$ & $<0.01$ & 0.64 & 0.10 & 0.29 \\
\cline { 2 - 8 } & Removed & 0.22 & & & 36.60 & 0.94 & -0.03 \\
\hline \multirow{3}{*}{14} & Feed & 0.08 & $<0.003$ & $<0.01$ & 5.21 & 0.14 & 0.04 \\
\cline { 2 - 8 } & Product & 0.61 & $<0.003$ & $<0.01$ & 0.34 & 0.11 & 0.07 \\
\cline { 2 - 8 } & Removed & -0.53 & & & 4.87 & 0.03 & -0.03 \\
\hline
\end{tabular}

Reactors 4, 5 (Fig. 3a-c) and 9-11 (Fig. 6a-c) lar to those recorded in fresh water (Reactors 4, 5 - Fig. demonstrate that the relative changes in water Eh and 3a-c and Reactors 9-11-Fig. 6a-c).

$\mathrm{pH}$ are similar for ZVM with a $50 \mathrm{~nm}$ and a $(44,000-$

Reactors 4, 5 (Fig. 4d) established an initial rise in $77,000 \mathrm{~nm}$ ) particle size. The Eh and $\mathrm{pH}$ changes are simi- EC which was followed by a very gradual EC decline. 

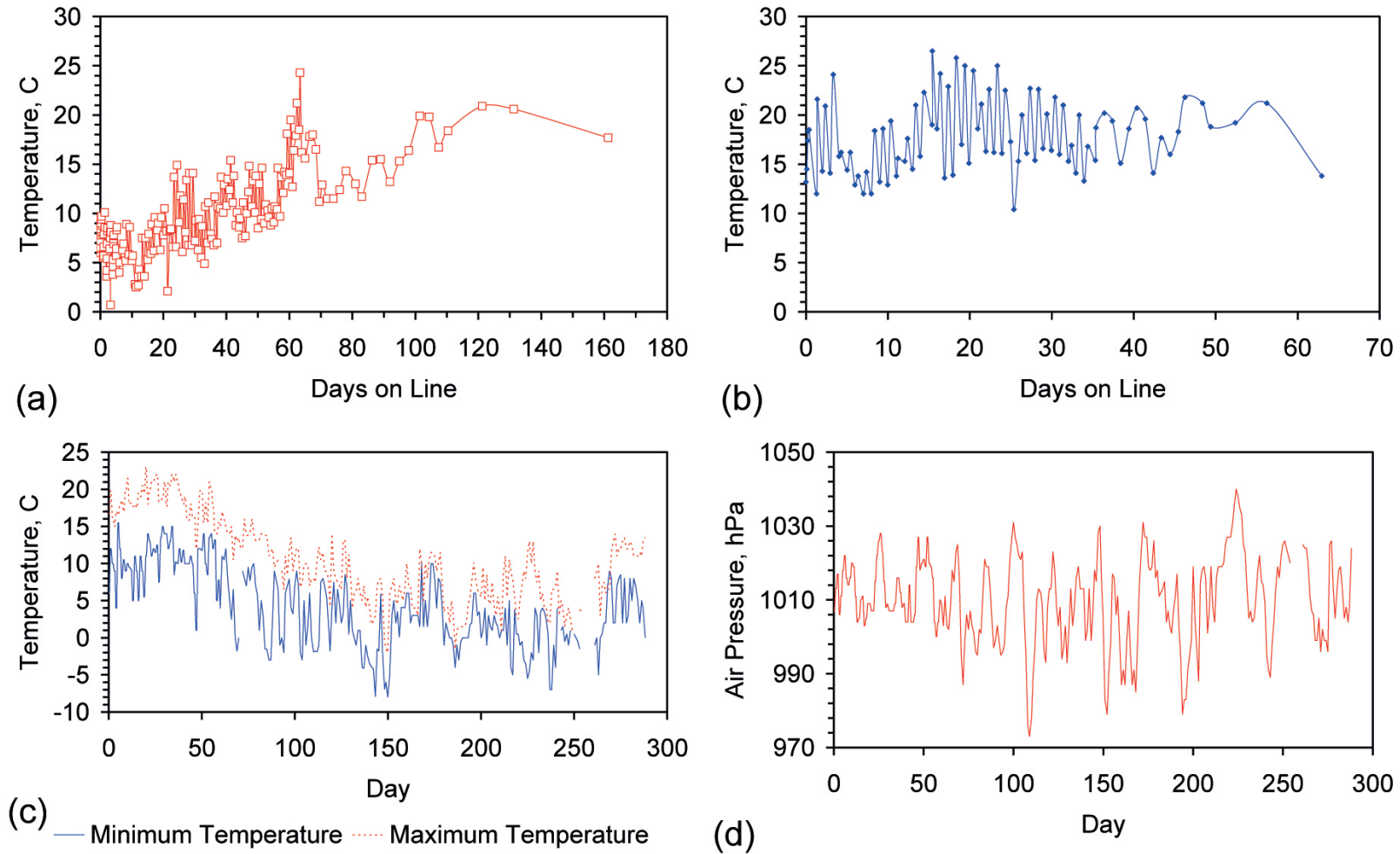

Fig. 1. Operating Temperatures and Pressures (a) Temperature vs. Days on Line, Reactors 1-3. (b) Temperature vs. Days on Line, Reactors 4, 5. (c) Temperature vs. Day. Reactors 6-14. (d) Atmospheric pressure vs. Day. Reactors 6-11, 13, 14

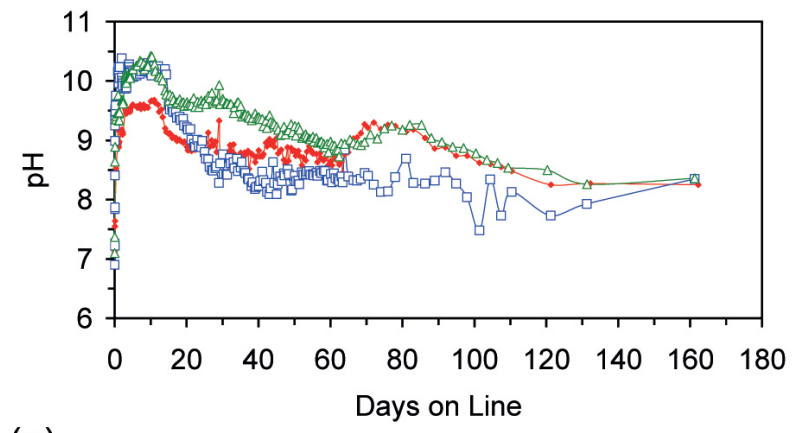

(a)
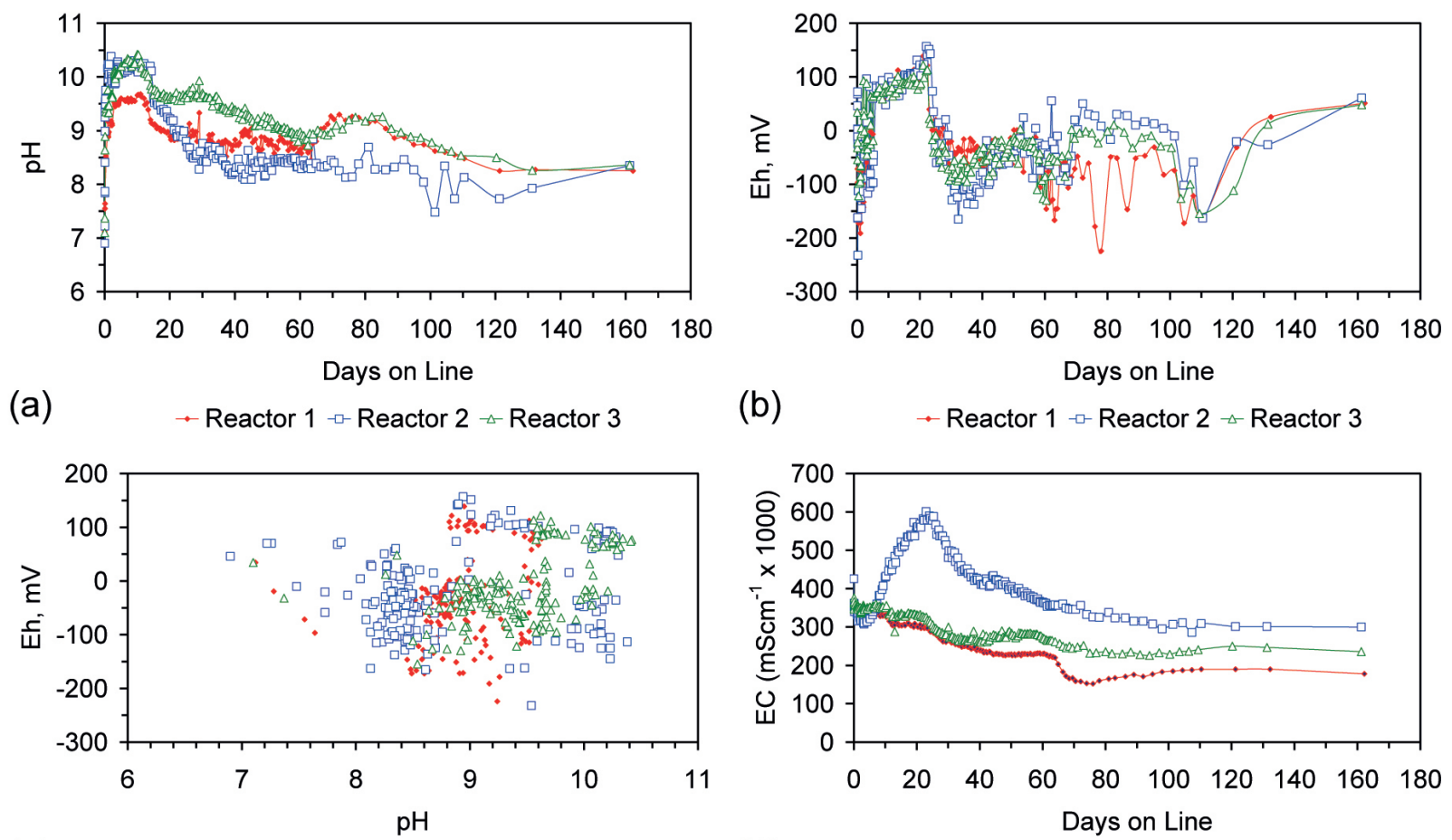

(c)

- Reactor $1 \square$ Reactor $2 \triangle$ Reactor 3

(b)

$\rightarrow$ Reactor $1 \rightarrow$ Reactor $2 \triangleleft$ Reactor 3

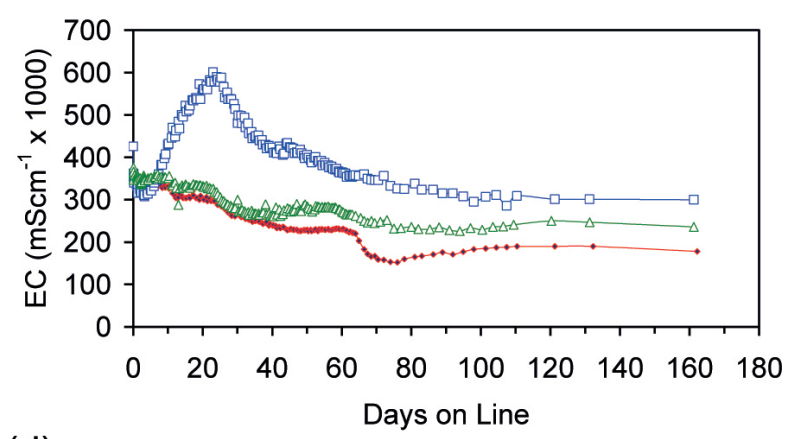

(d) $\rightarrow$ Reactor $1-$ Reactor $2 \triangleleft$ Reactor 3

Fig. 2. Product water associated with $\mathrm{n}-\mathrm{Fe}^{0}(44,000-77,000 \mathrm{~nm})$ with fresh (non-saline) feed water. (a) $\mathrm{pH}$ vs. time. (b) Eh vs. time. (c) Eh vs. pH. (d) EC vs. time

Reactors 9-11 (Fig. 6d) established an exponential decline in $\mathrm{EC}$ to a base level. The $\mathrm{EC}$ and $\mathrm{NaCl}$ declines were: (i) Reactor 4: maximum EC reduction (Fig. 3d) = $0.6 \mathrm{mScm}^{-1}\left(0.15 \mathrm{mScm}^{-1}\right.$ reduction from the feed water; Table 2). $\mathrm{NaCl}$ removed $=0.075-0.3 \mathrm{~g} \mathrm{NaCl} \mathrm{L}^{-1}$. (ii) Reac- tor 5: maximum EC reduction $=0.385 \mathrm{mScm}^{-1}$ (Fig. $\left.3 \mathrm{~d}\right)$ $\left(0.125 \mathrm{mScm}^{-1}\right.$ reduction from the feed water; Table 2). $\mathrm{NaCl}$ removed $=0.0675-0.1925 \mathrm{~g} \mathrm{NaCl} \mathrm{L}^{-1}$. (iii) Reactor 9: $\mathrm{EC}$ reduction $=2.073 \mathrm{mScm}^{-1}$ (Fig. $5 \mathrm{~d}-\mathrm{e}$ ). $\mathrm{NaCl}$ removed $=1.04-1.14 \mathrm{~g} \mathrm{NaCl} \mathrm{L}^{-1}$. (iv) Reactor 10: $\mathrm{EC}$ reduc- 


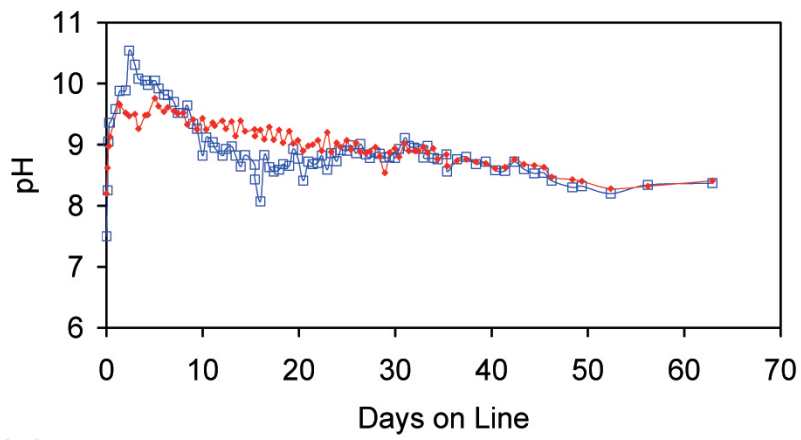

(a)

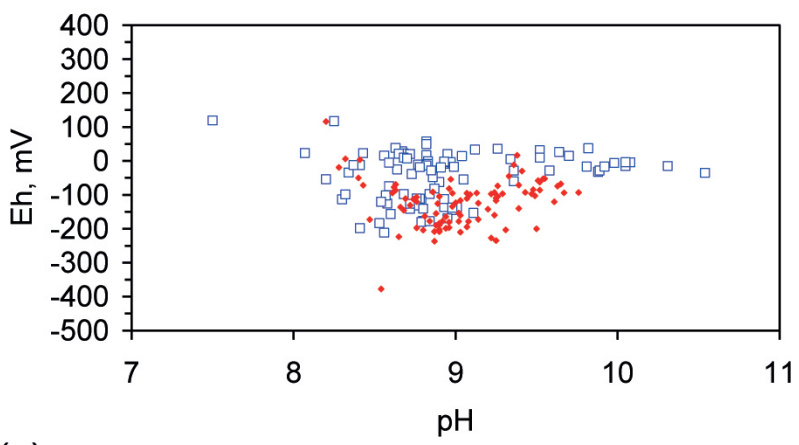

(c)

- Reactor 4 . Reactor 5

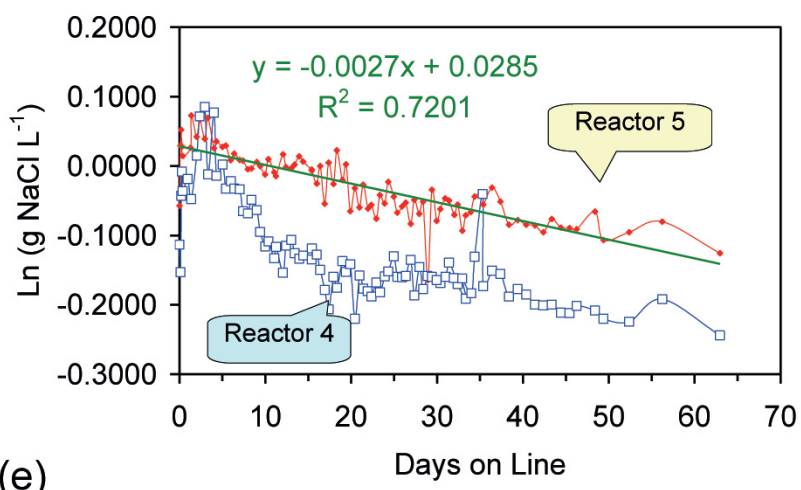

(e)

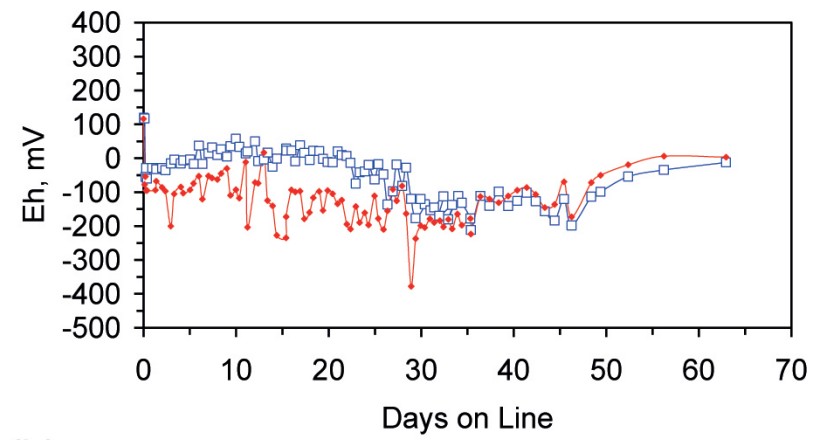

(b)

$\rightarrow$ Reactor $4 \rightarrow$ Reactor 5

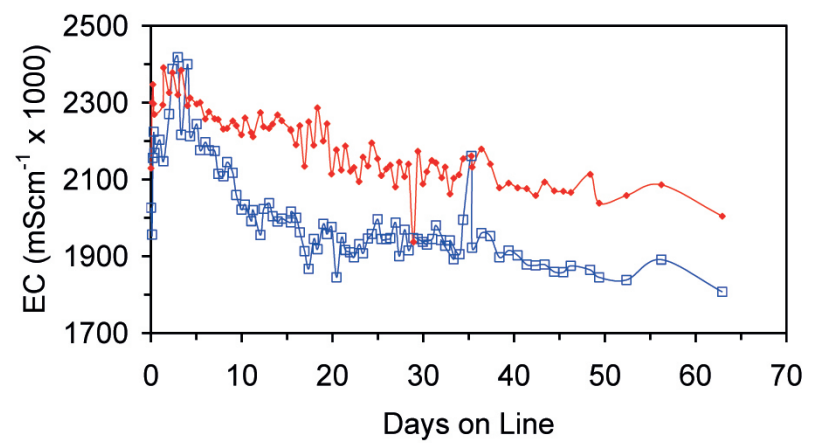

(d)

Fig. 3. Product water associated with n-Fe ${ }^{0}(44,000-77,000 \mathrm{~nm})$ with saline feed water. (a) pH vs. time. (b) Eh vs. time. (c) Eh vs. pH. (d) EC vs. time. (e) Water Salinity vs. time

tion $=1.952 \mathrm{mScm}^{-1}$ (Fig. $\left.5 \mathrm{~d}-\mathrm{e}\right) \mathrm{NaCl}$ removed $=0.976-$ $1.073 \mathrm{~g} \mathrm{NaCl} \mathrm{L}^{-1}$. (v) Reactor 11: EC reduction $=1.906$ $\mathrm{mScm}^{-1}$ (Fig. 5d-e) $\mathrm{NaCl}$ removed $=0.953-1.048 \mathrm{~g} \mathrm{NaCl} \mathrm{L}^{-1}$. About $0.06 \mathrm{~g} \mathrm{NaCl} \mathrm{g}^{-1} \mathrm{n}-\mathrm{Fe}^{0}$ was removed.

Reactors 9-11 demonstrate (Fig. 5e) that placement of $\mathrm{n}-\mathrm{Fe}^{0}$ in a saline water body can desalinate brackish water to potable levels $\left(\mathrm{EC}=\right.$ less than $\left.1 \mathrm{mScm}^{-1}\right)$.

$\mathrm{n}-\mathrm{Fe}^{0}$ desalination is associated with increasing $\mathrm{pH}$ and decreasing Eh (Fig. 3a-c, 5a-c). The salinity follows an exponential decline, from an initial salinity, before arriving at a base (or equilibrium) salinity [BS] (Fig. 5d-e). Graphical plots demonstrate (e.g. Ebbing and Gammon 1999) that the reaction order is not zero order (Fig. $5 \mathrm{~d}-\mathrm{e}$ ), first order (Fig. 5d-f), or second order (Fig. 5g). The rate of disappearance of $\left.\mathrm{NaCl} \mathrm{g} \mathrm{L}{ }^{-1}=\mathrm{k}[\mathrm{NaCl} \mathrm{g} \mathrm{L}]^{-1}\right]^{\mathrm{m}}$, where $\mathrm{k}$ is the rate constant and $\mathrm{m}=$ the reaction order (e.g. Ebbing, Gammon 1999).
The basic parameters which can be used to describe $\mathrm{n}-\mathrm{Fe}^{0}$ desalination (using $\mathrm{EC}$, or $\mathrm{g} \mathrm{L}^{-1}$ ) are: (i) the initial salinity [IS] (Table 2; Fig. 3d, 5d-e); (ii) the time [t] when the $\mathrm{EC}$ or salinity starts to decline $[\mathrm{t}=\mathrm{TS}]$. The salinity at $[\mathrm{TS}]=[\mathrm{IS}]$ (Fig. 3d, 5d-e); (iii) the time [t] when the EC or salinity ceases to decline $[\mathrm{t}=\mathrm{TC}]$ (Fig. $5 \mathrm{~d}$-e); (iv) the time [t] duration associated with desalination $[\mathrm{T}]$, where $[\mathrm{T}]=$ [TC] - [TS] (Fig. 5d-e); (v) the base salinity [BS] at [TC] (Fig. d-e). The controls on [TS], [TC], [BS], and [T] have not been defined in this study.

\section{3. $n-Z V M$ Impact of $\mathrm{N}_{2}$ Saturation: Particle Size: $50 \mathrm{~nm}$ : Surface Area $=20 \mathrm{~m}^{2} \mathrm{~g}^{-1}$.}

Reactor 12A demonstrated similar Eh and $\mathrm{pH}$ trends to Reactors 1 to 11 (Fig. 6a-c). The product gas from Reactor $12 \mathrm{~A}$ increased the Eh and $\mathrm{pH}$ in both Reactors $12 \mathrm{~B}$ and 


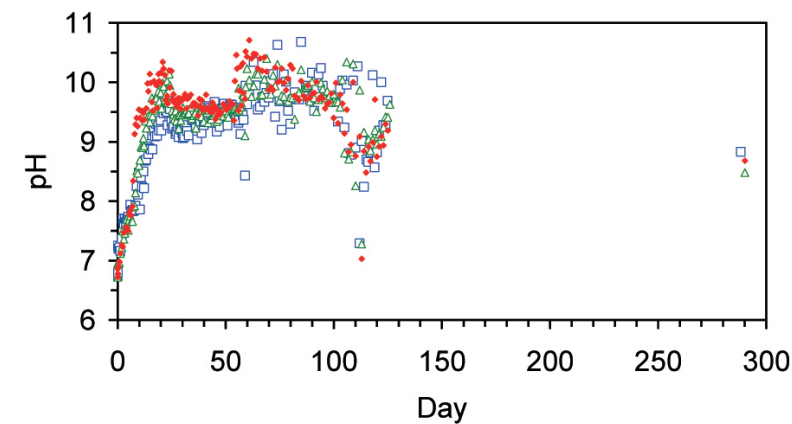

(a)

$\square$ Reactor $6 \Delta$ Reactor $7 \cdot$ Reactor 8

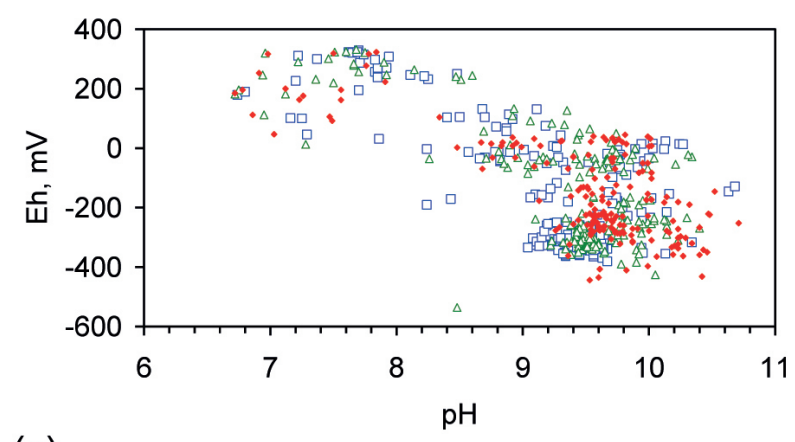

(c)

$\square$ Reactor $6 \triangle$ Reactor $7 \cdot$ Reactor 8

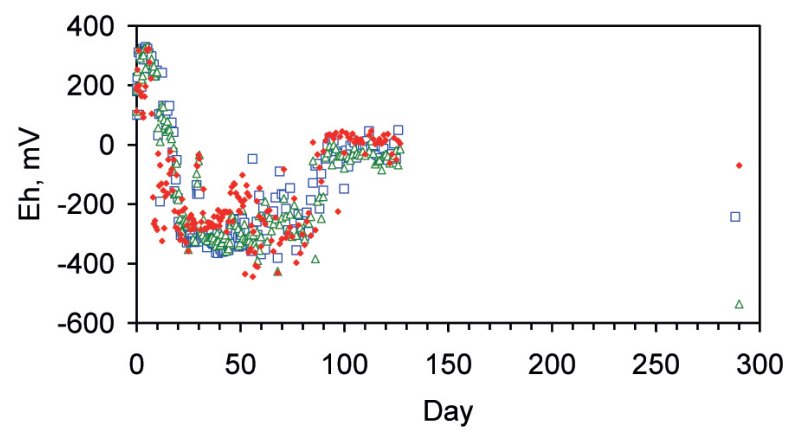

(b)

口 Reactor $6 \Delta$ Reactor 7 . Reactor 8

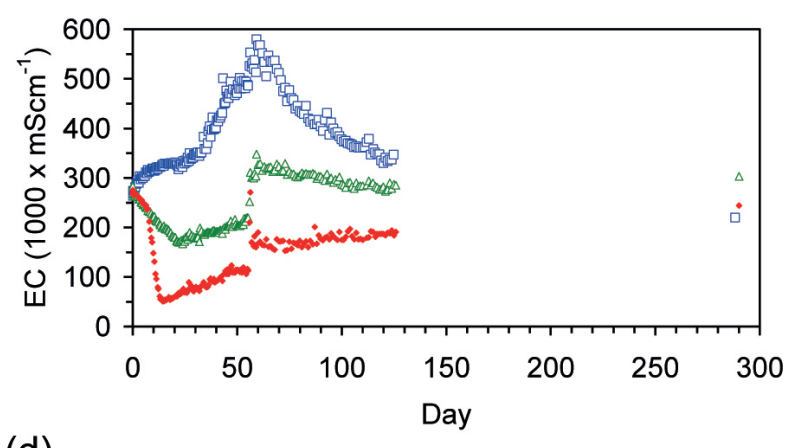

(d)

$\square$ Reactor $6 \triangle$ Reactor $7 \cdot$ Reactor 8

Fig. 4. Product water associated with n-Fe ${ }^{0}(50 \mathrm{~nm})$ with fresh (non-saline) feed water. (a) $\mathrm{pH}$ vs. time. (b) Eh vs. time. (c) Eh vs. pH. (d) EC vs. time

$12 \mathrm{C}$. The increase in $\mathrm{pH}$ and associated increase in EC is interpreted as indicating a decline in carbonyl and phenol concentrations in Reactor $12 \mathrm{C}$.

Reactor 12A, following the addition of $\mathrm{NaCl}$ (after 68-108 hrs on line), showed no noticeable desalination until additional $\mathrm{NaCl}$ was added after $608 \mathrm{hrs}$ on line (Fig. $6 \mathrm{~d}-\mathrm{e})$. Changes in salinity with time are punctuated and partially reversible within the reaction environment (Fig. 6e). Punctuated changes in reactant concentration, which are only partially reversible, are a characteristic of sequential reactions (e.g. McGeachy 2010). They indicate that the conditions which result in the first reaction becoming reversible may not apply to the second and subsequent reactions.

The product water from Reactors $12 \mathrm{~A}$ and $12 \mathrm{~B}$ were removed from the reactors and stored for 146 days prior to cation and anion analyses. This analysis is provided in Table 3: (i) Reactor A12A [on removal from the reactor: Eh $\left.=-0.25 \mathrm{~V} ; \mathrm{pH}=9.95 ; \mathrm{EC}=2.69 \mathrm{mScm}^{-1}\right] ;[146$ days after removal from the reactor: $\mathrm{Eh}=0.151 \mathrm{~V} ; \mathrm{pH}=7.24 ; \mathrm{EC}=$ $1.136 \mathrm{mScm}^{-1}$ ]; (ii) Reactor A12B [on removal from the reactor: $\left.\mathrm{Eh}=0.161 \mathrm{~V} ; \mathrm{pH}=8.73 ; \mathrm{EC}=5.88 \mathrm{mScm}^{-1}\right] ;[146$ days after removal from the reactor: $\mathrm{Eh}=0.158 \mathrm{~V} ; \mathrm{pH}=$ 7.15; $\mathrm{EC}=6.04 \mathrm{mScm}^{-1}$ ]. GC analyses of the gas composition produced by each reactor (Fig. 6h-i), indicate that the changes in Eh and $\mathrm{pH}$ in each reactor (Fig. 6a-b) may relate to the rate of hydrogen production in Reactor $12 \mathrm{~A}$.

The anion and cation analyses (Table 3 ) confirm removal of $\mathrm{Na}^{+}$and $\mathrm{Cl}^{-}$ions in Reactors 12A, 12B (Reactor
$12 \mathrm{~A}=9.693 \mathrm{~g} \mathrm{NaCl} \mathrm{L}^{-1}$; Reactor 12B $=1.564 \mathrm{~g} \mathrm{NaCl} \mathrm{L}^{-1}$ ) which are associated with the co-removal of a variety of anions and cations (Table 3).

Reactor 12B demonstrated (Table 3 ) an increase in [n$\mathrm{Fe}^{0}, \mathrm{Fe}^{\mathrm{n}+}, \mathrm{FeO}_{\mathrm{x}} \mathrm{H}_{\mathrm{y}}{ }^{\mathrm{n}+}$ ] concentrations to $0.0437 \mathrm{mg} \mathrm{L}^{-1}$ (for particles $<450 \mathrm{~nm}$ ), indicating that some $\mathrm{n}-\mathrm{Fe}^{0}$ may be entrained in the product gas exiting Reactor $12 \mathrm{~A}$ and entering Reactor 12B.

\subsection{Reuse of $n-Z V M$ modified by $N_{2}$ Saturation}

Reactor 12B (Fig. 6f; Table 3) raised the possibility that very low concentrations of n-ZVM could result in desalination occurring. This concept was tested in Reactors 13, 14 (Fig. 7) using low concentrations of ZVM (Table 2). The ZVM was extracted from Reactor 12A. The Eh, $\mathrm{pH}$ and EC changes (Fig. 7a-d) were consistent with those observed in Reactors 9-11 (Fig. 5a-d). Reactor 13 was terminated after 6 days (Fig. 7). Reactor 14 (Fig. 5, Table 3) confirmed an exponential salinity decline to a base salinity [BS], where $[\mathrm{BS}]=1.37 \mathrm{~g} \mathrm{NaCl} \mathrm{L}^{-1}$. Graphical plots confirm that the desalination reaction order is not 0,1 or 2 (Fig. 7e-g).

\subsection{Summary of Principal Observations}

The principal observations were:

1. $\mathrm{n}-\mathrm{Fe}^{0}$ and $\mathrm{ZVM}$ with a $44,000-77,000 \mathrm{~nm}$ particle size, 


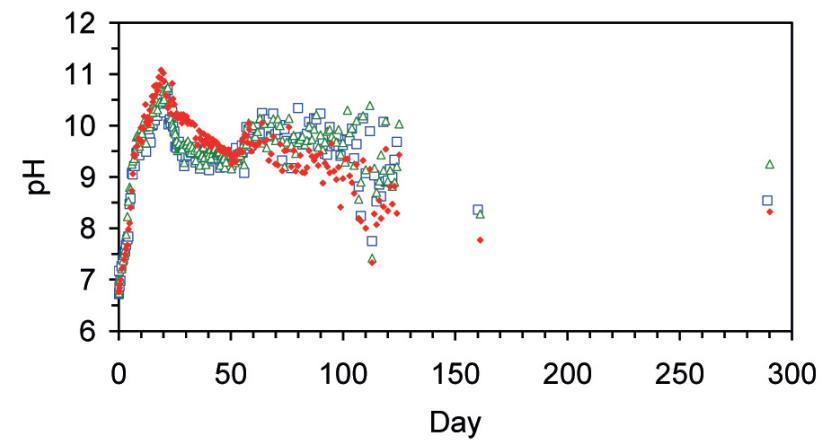

(a)

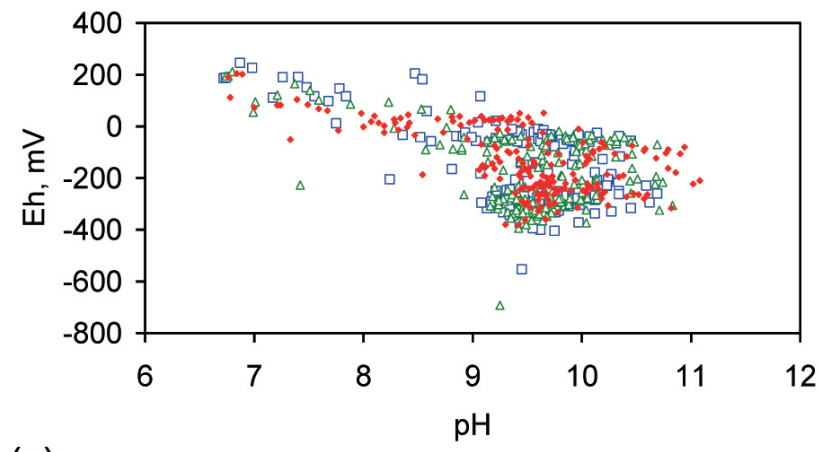

(c)
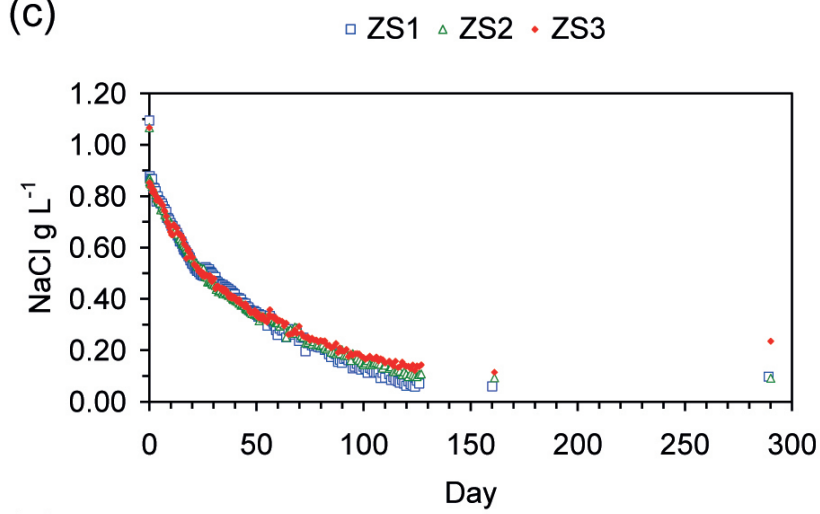

(e)

- Reactor $9 \Delta$ Reactor 10 . Reactor 11

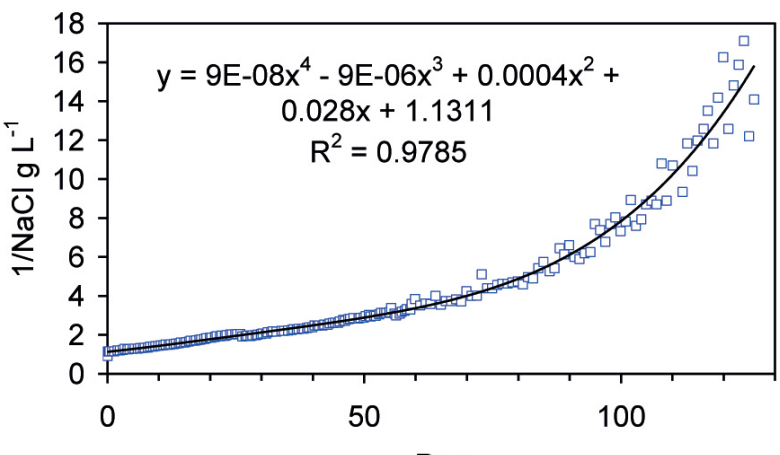

(g)

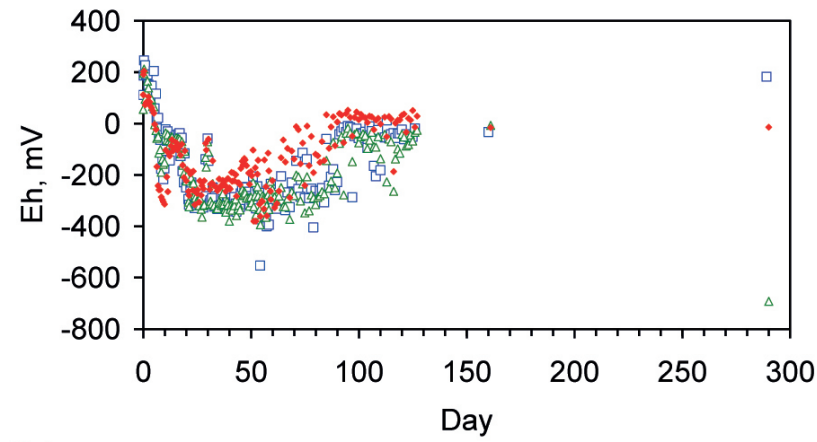

(b)

$\square$ Reactor $9 \Delta$ Reactor $10 \cdot$ Reactor 11

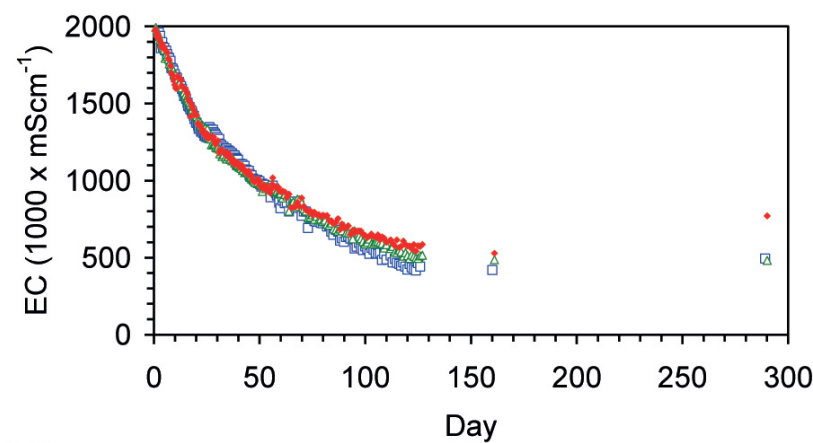

(d)

$\square$ Reactor $9 \Delta$ Reactor $10 \cdot$ Reactor 11

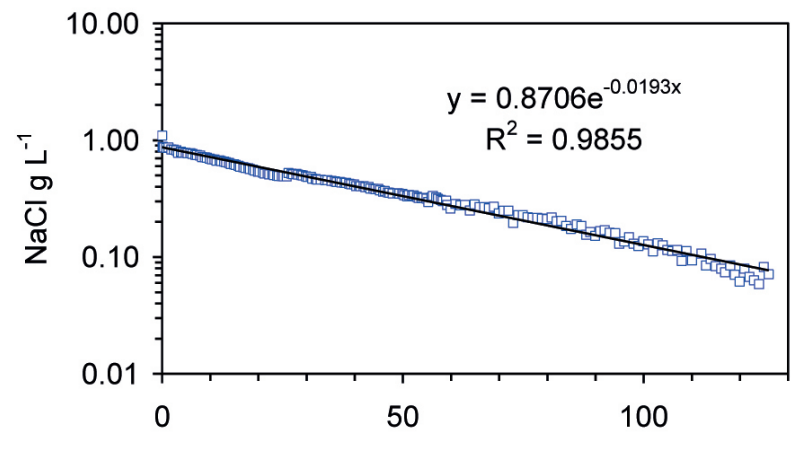

(f)

Day

Fig. 5. Product water associated with n-Fe $(50 \mathrm{~nm})$ with saline feed water. (a) pH vs. time. (b) Eh vs. time. (c) Eh vs. pH. (d) EC vs. time. (e) Water Salinity vs. time (Test for Zero Order Reaction). (f) Log [Water Salinity] vs. time for Reactor 9 (Test for First Order Reaction). (g) 1/[Water Salinity] vs. time for Reactor 9 (Test for Second Order Reaction)

when placed in fresh water, display similar changes in $\mathrm{EC}, \mathrm{Eh}$ and $\mathrm{pH}$. In saline water, the presence of $\mathrm{n}-\mathrm{Fe}^{0}$ accelerates the rate of EC (salinity) decline.

2. Placement of $n-\mathrm{Fe}^{0}$ in saline water which is saturated with a constant flow of $\mathrm{N}_{2}$, results in desalination of the water.

3. Placement of nitrogen treated $\mathrm{n}-\mathrm{Fe}^{0}$ in a saline water body can result in a substantial acceleration in the desalination rate, when compared with fresh $n-\mathrm{Fe}^{0}$. 


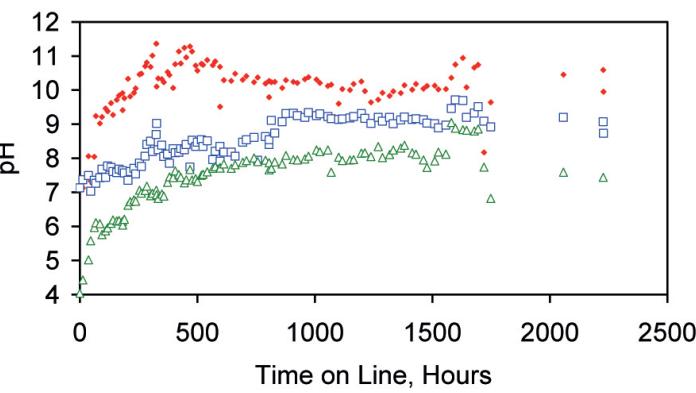

(a) $\cdot$ Reactor 12A $\square$ Reactor 12B $\triangle$ Reactor 12C

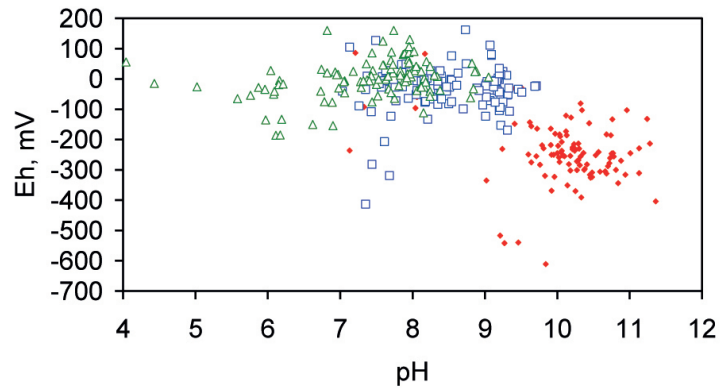

(c) $\quad$ Reactor 12A $\square$ Reactor 12B $\triangle$ Reactor 12C

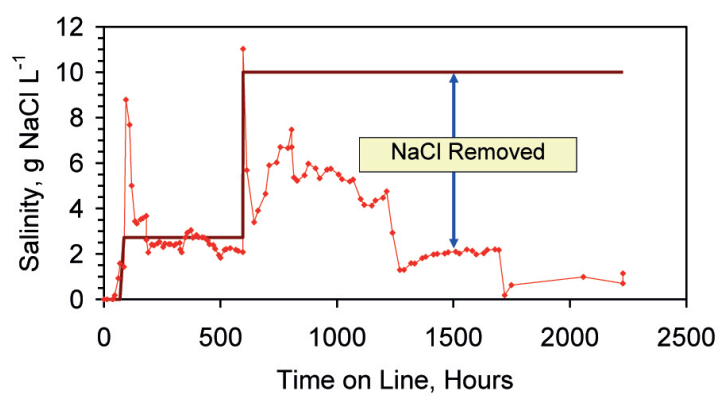

(e) $\rightarrow$ Product Water Salinity - Feed Water Salinity

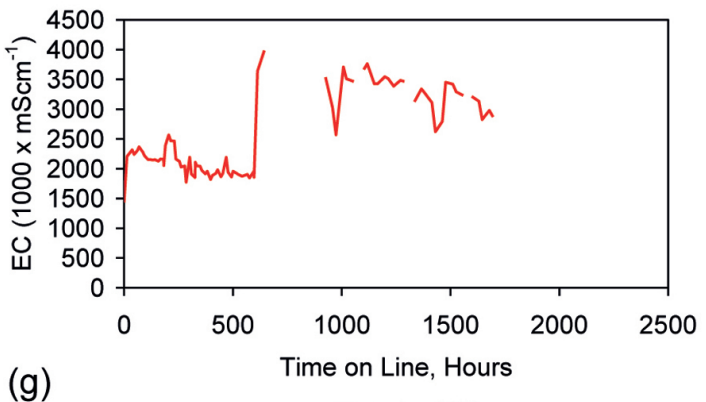

- Reactor $12 \mathrm{C}$

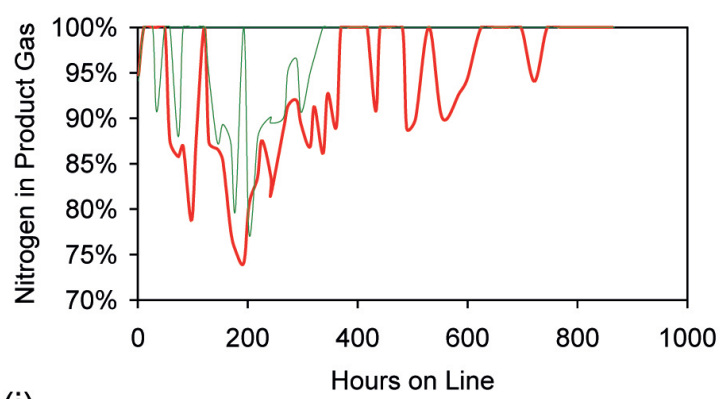

(i)

$$
\text { - Reactor } 12 \mathrm{~A} \text { - Reactor } 12 \mathrm{C}
$$

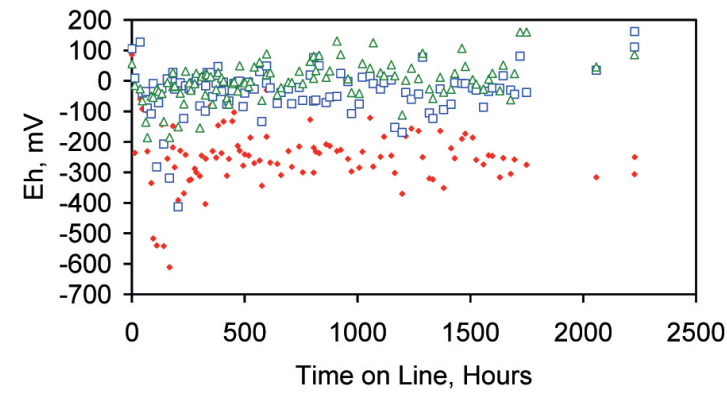

(b) $\cdot$ Reactor 12A $\square$ Reactor 12B $\triangle$ Reactor 12C

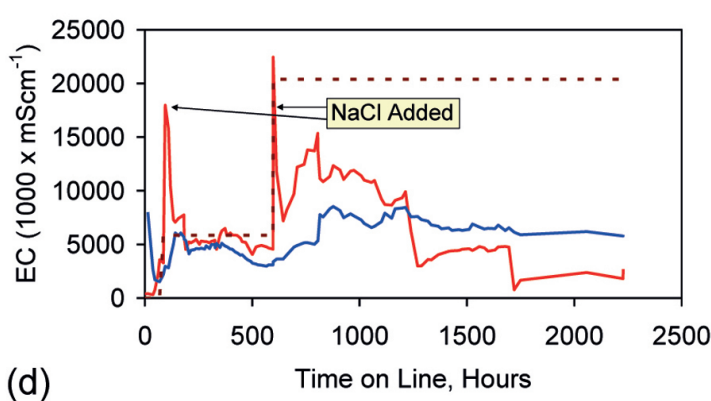

- Reactor 12A - Reactor 12B - - Feed Water (12A)

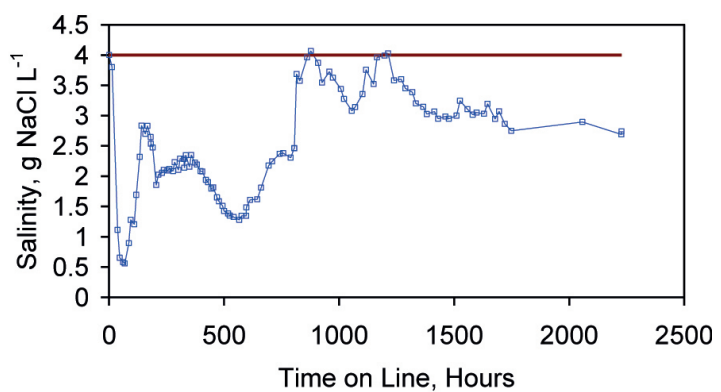

(f) Product Water Salinity - Feed Water Salinity

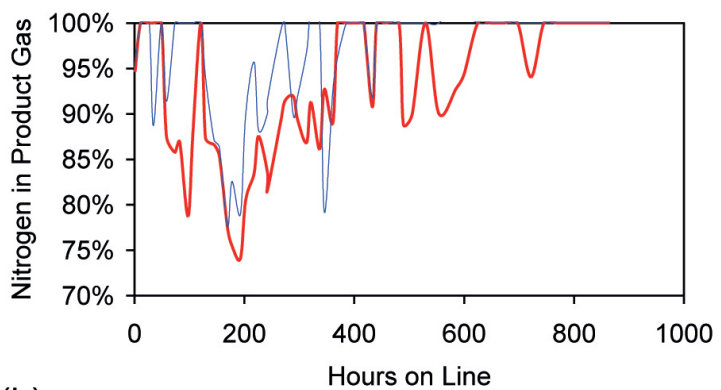

(h)

- Reactor $12 \mathrm{~A}$ - Reactor $12 \mathrm{~B}$

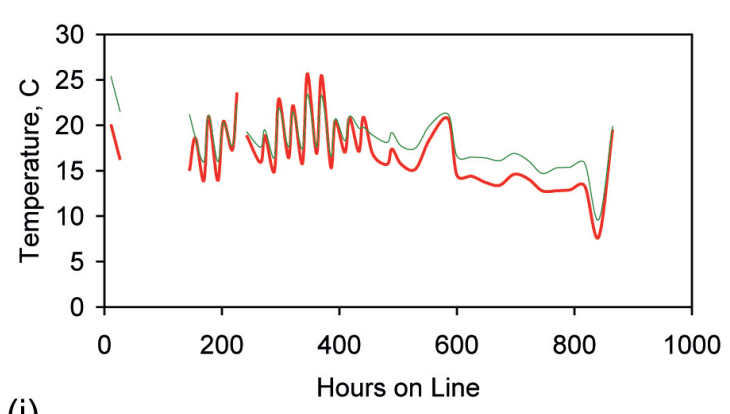

(j)

Fig. 6. Product water associated with $\mathrm{n}-\mathrm{Fe}^{0}(50 \mathrm{~nm})$ with saline feed water. (a) $\mathrm{pH}$ vs. time. (b) Eh vs. time. (c) Eh vs. pH. (d) EC vs. time. (e) Water Salinity [Reactor 12A] vs. time. (f) Water Salinity [Reactor 12B] vs. time. (g) EC [Reactor 12C] vs. time. (h) Nitrogen in product gas from Reactors $12 \mathrm{~A}, 12 \mathrm{~B}$ vs. time. Balance is $\mathrm{H}_{2}$. (i) Nitrogen in product gas from Reactors $12 \mathrm{~A}, 12 \mathrm{C}$ vs. time. Balance is $\mathrm{H}_{2}$. Product gas from Reactor $12 \mathrm{C}$ includes $0.05-0.3 \% \mathrm{CO}_{2}$. (j) Temperature vs. time 


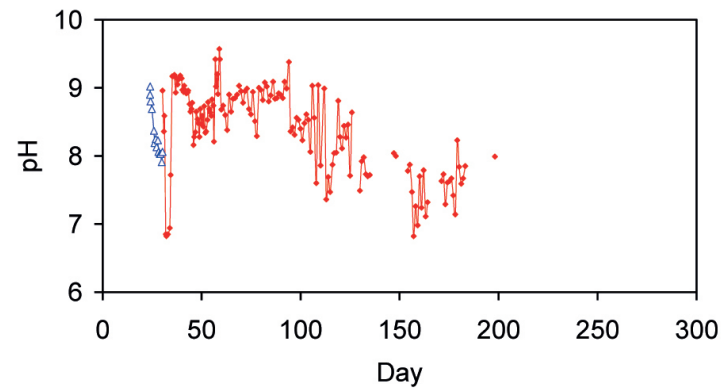

(a)

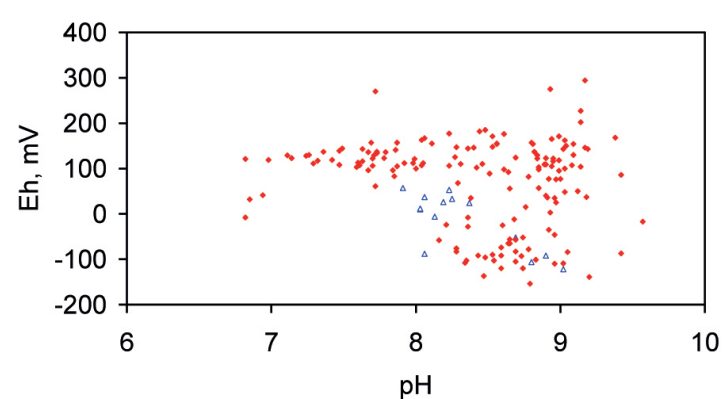

(c)

$\triangle$ Reactor $13 \cdot$ Reactor 14

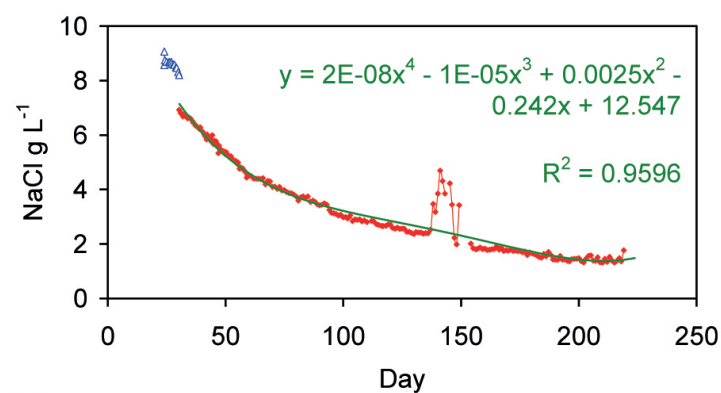

(e) $\triangle$ Reactor $13 \rightarrow$ Reactor $14-$ Poly. (Reactor 14)

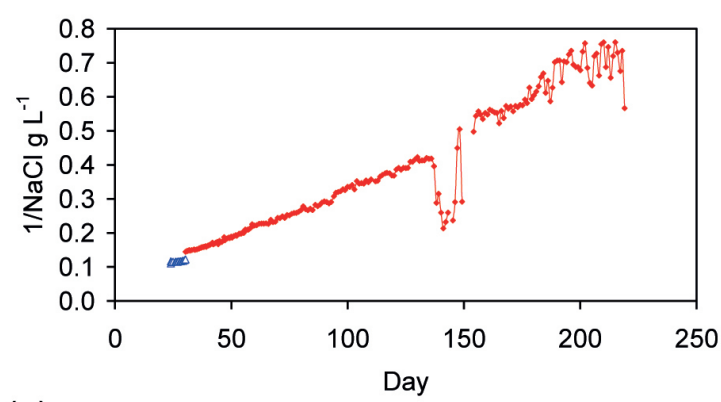

(g)

$\triangle$ Reactor $13 \rightarrow$ Reactor 14

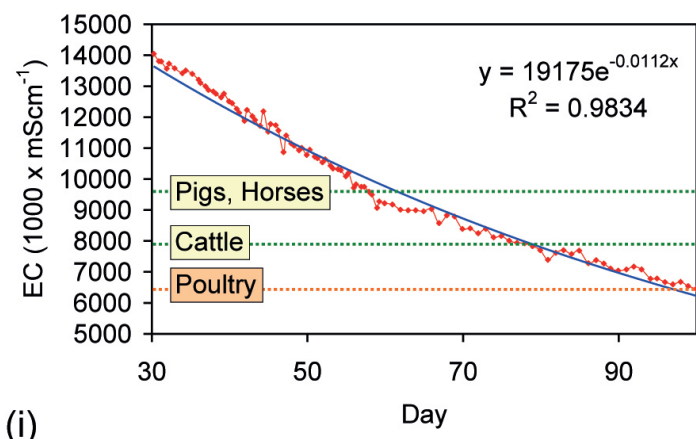

(i)

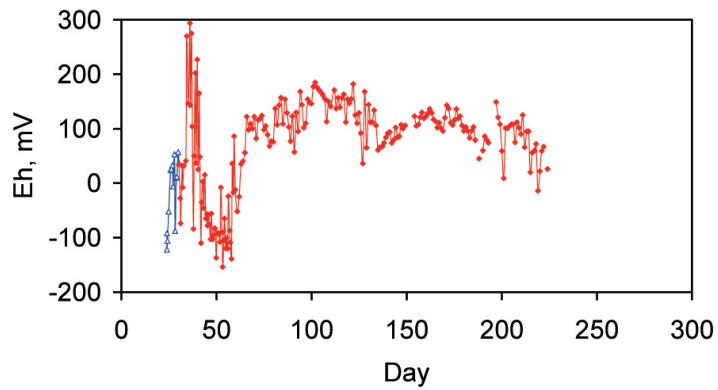

(b)

$\triangle$ Reactor $13+$ Reactor 14

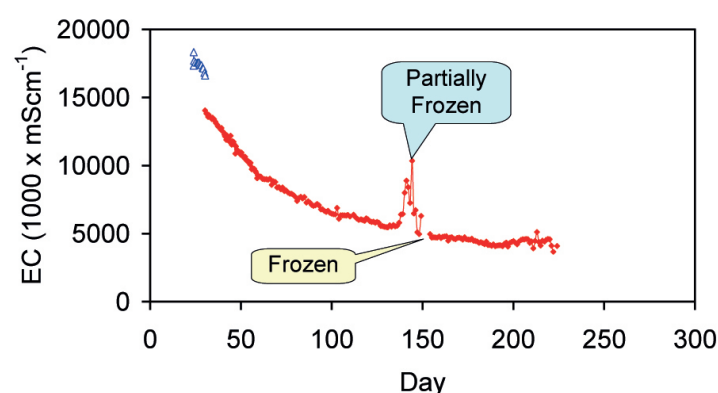

(d)

$\triangle$ Reactor $13 \rightarrow$ Reactor 14

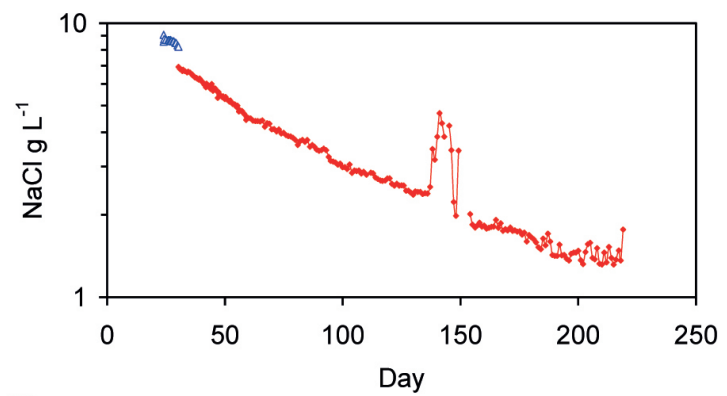

(f)

$\checkmark$ Reactor $13 \rightarrow$ Reactor 14

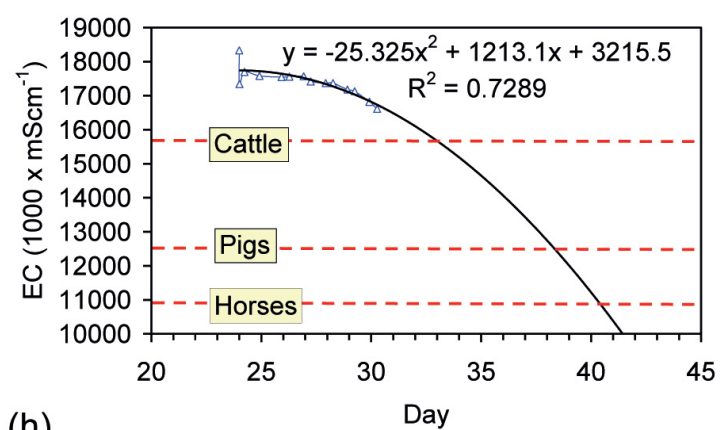

(h)

Fig. 7. Product water associated with $\mathrm{n}-\mathrm{Fe}^{0}(50 \mathrm{~nm})$ with saline feed water. (a) $\mathrm{pH}$ vs. time. (b) Eh vs. time. (c) Eh vs. pH. (d) EC vs. time. (e) Water Salinity vs. time. (f) Log [Water Salinity] vs. time. (g) 1/[Water Salinity] vs. time. (h) Reactor 13: Expected desalination as a function of time. (i) Reactor 14: Expected desalination as a function of time 

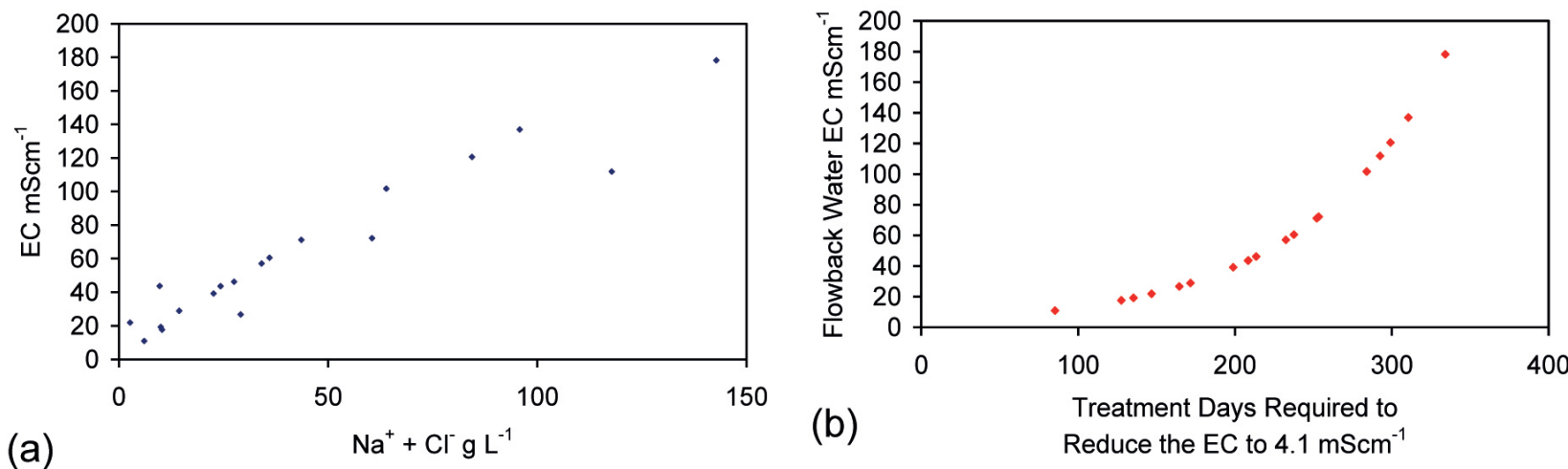

Fig. 8. Flowback Water Treatment (a) Salinity vs. EC. Marcellus Shale: Data from Haluszczak et al. (2013). (b) Expected treatment time (days) to achieve a salinity of $4.1 \mathrm{mScm}^{-1}$. EC data from Haluszczak et al. (2013). Desalination relationship used is from Fig. $7 \mathrm{i}$

\section{Discussion}

$\mathrm{NaCl}$ is either removed by adsorption (e.g. in a hydrated akaganeite structure, $\mathrm{FeO}(\mathrm{OH}) \cdot \mathrm{nH}_{2} \mathrm{O}$ (e.g. Yue et al. 2011), or green rust structure, or by $n-\mathrm{Fe}^{0}$ catalysis (e.g. Wilkin, McNeil 2003; Antia, 2014).

Comparison of: (i) Reactors 4, 5 (Fig. 3) with Reactors 9-11 (Fig. 5) demonstrates that the rate of $\mathrm{NaCl}$ removal is a function of the ZVM particle size, where the rate of desalination increases with decrea-sing particle size. (ii) Reactors 9-11 (Fig. 5) and Reactors 12A, 13, 14 (Fig. 6, 7) demonstrate that the rate of $\mathrm{NaCl}$ removal increases with increasing salinity of the feed water. This is consistent with an intrinsically higher order reaction adopting pseudo-order form (Carberry 2001).

Three reactors $(12 \mathrm{~B}, 13,14)$ established rates of $\mathrm{NaCl}$ removal that exceeded $1 \mathrm{~g} \mathrm{NaCl} \mathrm{g} \mathrm{Fe}{ }^{0}$ (Reactor $12 \mathrm{~B}=$ $39 \mathrm{~kg} \mathrm{NaCl} \mathrm{g}{ }^{-1} \mathrm{n}-\mathrm{Fe}^{0}$; Reactor $13=3.07 \mathrm{~g} \mathrm{NaCl} \mathrm{g}^{-1} \mathrm{n}-\mathrm{Fe}^{0}$; Reactor $\left.14=8.26 \mathrm{~g} \mathrm{NaCl} \mathrm{g}^{-1} \mathrm{n}-\mathrm{Fe}^{0}\right)$. These high removal rates cannot be explained by hydrated akaganeite formation (e.g. Yue et al. 2011) and may indicate the formation of nano- $\mathrm{FeOOH}(\mathrm{Cl})$ akaganeite polymers, polyionic iron-oxyhydroxide nanoparticles, $\mathrm{Na}_{\mathrm{w}} \mathrm{Fe}_{\mathrm{y}} \mathrm{O}_{\mathrm{x}} \mathrm{H}_{\mathrm{z}}$ and $\mathrm{Fe}_{\mathrm{m}} \mathrm{Al}_{\mathrm{n}} \mathrm{Cl}_{\mathrm{y}}(\mathrm{OH})_{\mathrm{q}}$ precipitated structures (e.g. Bottero et al. 1994; Dante et al. 1999; Antia, 2014; Sorokina, Dresvyannikov 2014).

The $\mathrm{n}-\mathrm{Fe}^{0}$ desalination process is an electrochemical redox process (e.g. Fig. 3, 5-7). Reactors 4, 5, 12A and 12B (Fig. 3,6) indicate that the desalination process involves redox switchable material, where desalination commences at a time, $\mathrm{t}=\mathrm{TS}$, and is concluded at time, $\mathrm{t}=$ [TC]. The $n-\mathrm{Fe}^{0}$ is placed in the water at time $(\mathrm{t}=0)$, and TS is greater than 0 .

Electrochemical redox switchable moieties using ferrocene $[\mathrm{FC}]$ and related species have been demonstrated (e.g. Muraoka et al. 2001; Arumugam et al. 2013; Varnado et al. 2013). The basic operational stages of a redox switchable moiety are: (i) Stage 1 . The initial state (at $t=0$ ) is a solid surface + ionic liquid (e.g. $\mathrm{Fe}^{0}+\mathrm{Na}^{+}+\mathrm{Cl}^{-}$). (ii)
Stage 2. The solid surface is then modified in an elution stage to contain tethered cathodic (e.g. $\mathrm{H}^{+}, \mathrm{FeH}^{\mathrm{n}+}, \mathrm{FeO}$ $(\mathrm{OH})_{\mathrm{n}}{ }^{\mathrm{+}}$ ) groups and tethered anodic (e.g. $\mathrm{O}^{\mathrm{n}-}, \mathrm{OH}^{-}, \mathrm{O}_{2} \mathrm{H}^{-}$, $\left.\mathrm{FeO}(\mathrm{OH})_{\mathrm{n}}{ }^{\mathrm{x}}\right)$ groups. These tethered sites can include akaganeite. (iii) Stage 3. The tethered cathodic groups form ion adducts with the $\mathrm{Cl}^{-}$ions. The tethered anodic groups form ion adducts with the $\mathrm{Na}^{+}$ions.

Under the redox switchable model, Stage 2 commences at [TS], and the time interval [T] represents the combined operation of Stages 2 and 3. [BS] represents the residual water salinity when the tethered anodic and cathodic groups are saturated. The punctuated (and reversible) EC changes observed in Reactors 12A (Fig. 6e), 12B (Fig. 6f) and 14 (after Day 184 (Fig. 7f)) are consistent with this model.

\section{1. $n-F^{0}{ }^{0}$ Desalination Mechanism}

The Eh and $\mathrm{pH}$ regimes in each reactor (Fig. 2-7) indicate that the dominant $\mathrm{Fe}^{0}$ corrosion species is $\mathrm{FeOOH}$ (Pourbaix 1974). The dominant $\mathrm{Fe}^{\mathrm{III}}$ corrosion product will be goethite and lepidocrocite in the fresh water reactors (Fig. 2, 4) and akaganeite in the saline water reactors (Fig. 3, 5-7).

The rate of desalination associated with $\mathrm{n}-\mathrm{Fe}^{0}(50 \mathrm{~nm})$ (Fig. 5) is greater than the rate of desalination associated with $\mathrm{Fe}^{0}(44,000-77,000 \mathrm{~nm})$ (Fig. 3). This indicates that the desalination rate $\left(k_{\text {observed }}\right)$ is a function of particle surface area $\left(a_{s}\right)$, i.e. $k_{\text {observed }}=k a_{s} P_{w}$ (Wilkin, McNeil 2003), where $k=$ the desalination rate, $P_{w}=\mathrm{n}-\mathrm{Fe}^{0}$ loading, $\mathrm{g} \mathrm{n}-\mathrm{Fe}^{0} \mathrm{~L}^{-1}$. This observation is consistent with $\mathrm{NaCl}$ removal by adsorption onto the particle surface. The measured $\mathrm{Na}: \mathrm{Cl}$ adsorption ratios were 1.05:1 (Reactor 12A, Table 3) and 1:1 (Reactor 14, Table 3) relative to the feed water concentrations.

In each example, the final product water salinity level was different (i.e. Reactors 9, 10, $11=0.1-0.2 \mathrm{~g} \mathrm{~L}^{-1}$; Reactor $12 \mathrm{~A}=1 \mathrm{~g} \mathrm{~L}^{-1}$; Reactor $14=2 \mathrm{~g} \mathrm{~L}^{-1}$ ). The stable final 
salinity develops under conditions where Eh rises and $\mathrm{pH}$ is stable (Fig. 5-6), or Eh is stable and pH declines (Fig. 7). This demonstrates that desalination termination is controlled by the relative availability of $\mathrm{H}^{+}$and $\mathrm{e}^{-}$. This is indicative of a redox switchable moiety (Shimakoshi et al. 2009), and implies that the self assembly ZVM corrosion products, which have removed the $\mathrm{NaCl}$, are structured to contain cathodic and anodic components (Antia 2014).

\subsection{Significance of Temperature}

The temperatures associated with desalination (Fig. 1, $6 j$ ) were within the range $0-25^{\circ} \mathrm{C}$. The associated pressures were atmospheric pressure (Reactors 4, 5, 9, 10, 11, 13, 14 - Fig. 1) and between 0 and $0.1 \mathrm{MPa}$ (Reactor 12A). Reverse osmosis plants are operated at atmospheric temperature $\left(0-55^{\circ} \mathrm{C}\right)$ and 1.5 to $8 \mathrm{MPa}$ pressure. Multi Stage Flash Distillation plants are operated at elevated temperatures $\left(120-200^{\circ} \mathrm{C}\right)$ and 1 to $10 \mathrm{MPa}$ pressure. This study has demonstrated that unlike conventional desalination plants, $\mathrm{n}-\mathrm{Fe}^{0}$ desalination can be operated at atmospheric temperatures and pressures.

\subsection{Cations and Anions Removed}

$\mathrm{n}-\mathrm{Fe}^{0}$ can remove a range of cations, anions and microbiota (e.g. Antia 2014). Reactors $12 \mathrm{~A}$ and 14 (Table 3) demonstrate co-removal of (i) anions $\left(\mathrm{Cl}^{-}, \mathrm{NO}_{3}{ }^{-}, \mathrm{SO}_{4}{ }^{2-}\right)$; and (ii) cations (B, Ba, $\mathrm{Ca}, \mathrm{Na}, \mathrm{Mg}, \mathrm{S}, \mathrm{Si}, \mathrm{Sr})$. The Eh and $\mathrm{pH}$ conditions observed in Reactors $12 \mathrm{~A}$ and 14 (Fig. 6-7) will allow: (i) nitrates to be removed as nitrites and $\mathrm{N}$ (aq) (Pourbaix 1974); (ii) $\mathrm{Ca}$ to be removed as $\mathrm{Ca}(\mathrm{OH})_{2}$ precipitates (Pourbaix 1974). Removal of the $\mathrm{SO}_{4}{ }^{2-}$ anion and $(\mathrm{B}, \mathrm{Ba}, \mathrm{Mg}, \mathrm{S}, \mathrm{Si}, \mathrm{Sr})$ cations is not expected under the observed Eh and pH conditions (Pourbaix 1974) unless they have been incorporated into green rust (layered double hydroxide) structures accreting onto the corroding $\mathrm{n}-\mathrm{Fe}^{0}$ particles (Ruby et al. 2006). Their removal confirms that the desalination process is associated with the formation of both $\mathrm{FeOOH}$ and the layered double hydroxides.

\subsection{Eh and $\mathrm{pH}$}

The Eh and $\mathrm{pH}$ of the water defines the equilibrium constants, reaction quotients, Gibbs Free Energy, and Heat of Formation for each potential reaction involving anions and cations dissolved in water (Pourbaix 1974; Ebbing, Gammon 2009; Antia 2014). Oscillations in Eh and pH, and associated changes over time (Fig. 2-7), result in predictable fluctuations in each of these parameters (Pourbaix 1974; Antia 2014) and control the direction of equilibrium reactions (Pourbaix 1974). The observed Eh, pH (Fig. 2-7) indicated that any $\mathrm{Fe}^{\mathrm{n}+}$ species present in the water would be removed as $\mathrm{Fe}^{\mathrm{III}}$ precipitants (e.g. $\mathrm{FeOOH}$ ). Cation analyses of the water (Table 3 ) confirmed that any dissolved $\mathrm{Fe}^{\mathrm{n}+}$ species had been removed as precipitants.

\section{Applications}

The desalination technology demonstrated by Reactors 9-14 requires testing at a commercial scale in order to demonstrate reproducibility and obtain certification and regulatory approvals. This study has not sought to optimise the amount $[\mathrm{A}]$ of water treated $\mathrm{t}^{-1} \mathrm{n}-\mathrm{Fe}^{0}$ required $\left(\mathrm{m}^{3}\right.$ water $\left.\mathrm{t}^{-1}\right)$. The indicated amounts of $[\mathrm{A}]$ are: (i) Reactor 13: $3570 \mathrm{~m}^{3} \mathrm{t}^{-1} \mathrm{Fe}^{0}$; (ii) Reactor 14: $1470 \mathrm{~m}^{3} \mathrm{t}^{-1} \mathrm{Fe}^{0}$; (iii) Reactor 12B: $57185 \mathrm{~m}^{3} \mathrm{t}^{-1} \mathrm{Fe}^{0}$. [T] falls in the range 6200 days.

A precise cost evaluation for a remediation desalination cannot be defined solely on the grounds of laboratory scale tests, but must take into account the results of pilotscale tests performed in the field, considering the chemistry of the local feed water. At this time it is not known how high levels of contaminants in water, (e.g. sulphates, sulphides, bicarbonate, carbonate, phosphate, nitrates, organic anions, and metal cations) may interfere with the desalination process.

\subsection{ZVM Costs}

n-Fe ${ }^{0}$ (Nanofer Star, www.nanoiron.cz) currently (22 April 2015) retails at around $\$ 53 / \mathrm{kg}$ for small quantities (3 kg). The price (for $3 \mathrm{~kg}$ ) varies from Euros $42 / \mathrm{kg}$ (EU delivery) to $61 / \mathrm{kg}$ (Countries outside the EU and North America). Volume manufacturers of $n-\mathrm{Fe}^{0}$ in China are able to deliver up to $800 \mathrm{t} /$ contract. FOB prices quoted (www.alibaba.com and www.made-in-china.com on 17 April, 2015) by Chinese manufacturers for high volume orders (more than $10 \mathrm{t}$ ) start at US\$600-33,000 $\mathrm{t}^{-1}$.

An initial economics screening based on a delivered $\mathrm{n}-\mathrm{Fe}^{0}$ price (base cost, BP) of US\$53,000 $\mathrm{t}^{-1}$ (Nanofer Star) is used in this study to indicate the potential viability of the technology. It is possible that commercial negotiations with a suitable supplier may be able to reduce the effective cost of the $n-\mathrm{Fe}^{0}$ into the range US\$2,000 to US\$15,000 $\mathrm{t}^{-1}$ (PCR).

Nanofer Star provides a potential desalination cost of: (i) (Reactor 12B), $\mathrm{BP}=\$ 5 \mathrm{~m}^{-3}, \mathrm{PCR}=\$ 0.18-1.41 \mathrm{~m}^{-3}$; (ii) (Reactor 13), $\mathrm{BP}=\$ 17 \mathrm{~m}^{-3}, \mathrm{PCR}=\$ 0.64-4.81 \mathrm{~m}^{-3}$; (iii) (Reactor 14), $\mathrm{BP}=\$ 36 \mathrm{~m}^{-3}, \mathrm{PCR}=\$ 1.35-10.18 \mathrm{~m}^{-3}$.

These cost estimates, exclude costs associated with $\mathrm{N}_{2}$, or $\mathrm{N}_{2}+\mathrm{H}_{2}$ processing, transport costs and delivery mecha- 
nisms and facilities for the desalination. These desalination costs indicate that $\mathrm{n}-\mathrm{Fe}^{0}$ desalination has potential applications for the treatment of relatively small volumes of water (e.g. less than $10-100,000 \mathrm{~m}^{3}$ ), particularly in areas with limited infrastructure.

\subsection{Potable Water}

Potable (drinking) water standards vary internationally and include a large number of factors other than salinity (e.g. EU 1998; WHO 2006). Reduction of water salinity to less than $0.5 \mathrm{~g} \mathrm{NaCl} \mathrm{L}^{-1}$ (e.g. EU 1998), or 0.25$0.6 \mathrm{~g} \mathrm{Cl} \mathrm{L}^{-1}+$ less than $0.2 \mathrm{~g} \mathrm{Na}^{+} \mathrm{L}^{-1}$ (WHO 2006) can be regarded as a first stage in creating potable water. In some countries (e.g. India) acceptable potable water can include $1 \mathrm{~g} \mathrm{Cl}^{-} \mathrm{L}^{-1}$ (IS 2012). $\mathrm{pH}$ limits range from 8.5 (IS 2012) to 9.5 (EU 1999) to no restriction (WHO 2006). The $\mathrm{pH}$ associated with the product water from Reactors 9-11 (Fig. 5) complies with the Indian and EU limits. The product water from Reactor 12A (Fig. 6) complies with the WHO definition of potable water.

A potable water $\mathrm{NaCl}$ standard of less than $0.5 \mathrm{~g} \mathrm{~L}^{-1}$ was achieved by Reactors 9-11 $\left(\mathrm{BP}=\$ 883 \mathrm{~m}^{-3} ; \mathrm{PCR}=\$ 33.3\right.$ $\left.250 \mathrm{~m}^{-3}\right)$ and Reactor $12 \mathrm{~A}\left(\mathrm{BP}=\$ 1445 \mathrm{~m}^{-3} ; \mathrm{PCR}=\$ 54.5\right.$ $\left.409 \mathrm{~m}^{-3}\right)$.

The high cost of treating water to potable levels using $\mathrm{n}-\mathrm{Fe}^{0}$ indicates that its commercial application will be restricted to low volume treatments, and the treatment of water in areas with no infrastructure (or destroyed infrastructure). These costs are comparable with the $\$ 600 \mathrm{~m}^{-3}+$ capital cost + installation costs + transport costs + energy costs associated with some small membrane units (e.g. Butler 2012; Butler et al. 2013).

WHO (2011) guidelines identify that the water requirement following a disaster/emergency are 7.5-15 $\mathrm{L} \mathrm{d}^{-1}$ person $^{-1}$ for potable water. Reactor 12A establishes (Fig. 6 ) that a series of compact reactor units batch processing $100 \mathrm{~m}^{3}$ on a 46 day cycle will produce about $2 \mathrm{~m}^{3} \mathrm{~d}^{-1}$. This unit could provide decontaminated survival water for a community of $130-260$ people for a $\mathrm{n}-\mathrm{Fe}^{0}$ cost of $\$ 0.419$ $22 \mathrm{~d}^{-1}$ person $^{-1}$. The concurrent biological and pollutant decontamination of the water (Antia 2014) will potentially reduce the health costs associated with an emergency.

\subsection{Emergency Livestock Water}

In an emergency livestock can utilize water with an elevated salinity (e.g. Curran 2007). WHO (2011) recommends that in an emergency, livestock should receive the following: (i) cattle, horses, and mules $=20-30 \mathrm{~L} \mathrm{~d}^{-1}$; (ii) goats, sheep and pigs $=10-20 \mathrm{~L} \mathrm{~d}^{-1}$; (iii) poultry $=0.1$ -
$0.2 \mathrm{~L} \mathrm{~d}^{-1}$. Livestock feed water is not of potable quality as most livestock are tolerant of high salt levels (e.g. Curran 2007; German et al. 2008).

Curran (2007) defines three groups of water salinity for each livestock type: (i) water salinity which has no adverse effects on livestock. This varies from $0-3.1 \mathrm{mScm}^{-1}$ for poultry to $0-7.8 \mathrm{mScm}^{-1}$ for sheep. (ii) water salinity which livestock may be reluctant to drink, but can adapt to without loss of production. This varies from 3.1-4.7 $\mathrm{mScm}^{-1}$ for poultry to $7.8-15.6 \mathrm{mScm}^{-1}$ for sheep. (iii) water salinity which livestock can tolerate for short periods without a marked decline in health and condition. This varies from 4.7-6.3 $\mathrm{mScm}^{-1}$ for poultry to $15.6-20.3 \mathrm{mScm}^{-1}$ for sheep.

Following a disaster (e.g. drought, earthquake, etc.) the available water may be highly salinized. Reactors 13,14 established (Fig. 7) that placement of ZVM in the water can reduce its salinity.

Example 1 (based on Reactor 13): Available livestock feed water $\mathrm{EC}=18.3 \mathrm{mScm}^{-1}$ : (i) $\mathrm{EC}$ decline follows a polynomial function (Fig. 7h). (ii) extrapolation of the function over a 15 to 20 day period (Fig. 7h) establishes that (a) after 9 days the salinity will be less than $15.6 \mathrm{mScm}^{-1}$ (beef cattle survival limit); (b) after 15 days the salinity will be less than $12.5 \mathrm{mScm}^{-1}$ (pig survival limit); (c) after 17 days the salinity will be $<10.9 \mathrm{mScm}^{-1}$ (horse and dairy cattle survival limit). The cost of providing desalinated water following an emergency to maintain a population of: (i) 100 cattle or horses is $\mathrm{BP}=\$ 51 \mathrm{~d}^{-1} ; \mathrm{PCR}=\$ 1.92-14.4 \mathrm{~d}^{-1}$; (ii) 100 pigs is $\mathrm{BP}=\$ 34 \mathrm{~d}^{-1}, \mathrm{PCR}=\$ 1.28-9.62 \mathrm{~d}^{-1}$.

Example 2 (based on Reactor 14): Available livestock feed water $\mathrm{EC}=14.05 \mathrm{mScm}^{-1}$ : (i) $\mathrm{EC}$ decline follows an exponential function (Fig. 7i). (ii) Fig. 7i establishes that continued treatment of the water would reduce the EC progressively to allow horses $\left(\mathrm{EC}=\right.$ less than $\left.9.4 \mathrm{mScm}^{-1}\right)$, pigs $\left(\mathrm{EC}=\right.$ less than $\left.9.4 \mathrm{mScm}^{-1}\right)$ and cattle $(\mathrm{EC}=$ less than $7.8 \mathrm{mScm}^{-1}$ ) to fatten. After about 70 days treatment the water would be suitable for poultry. The cost of providing desalinated water following an emergency to maintain a population of: (i) 100 cattle or horses is $\mathrm{BP}=\$ 108 \mathrm{~d}^{-1}$; $\mathrm{PCR}=\$ 4.07-30.5 \mathrm{~d}^{-1}$; (ii) 100 pigs is $\mathrm{BP}=\$ 72 \mathrm{~d}^{-1}$; PCR $=\$ 2.7-20.4 \mathrm{~d}^{-1}$.

This analysis indicates that $\mathrm{n}-\mathrm{Fe}^{0}$ could be used in disaster relief to provide usable water for livestock at a reasonable cost.

\subsection{Impoundment Water}

Impoundments are extensively used in the USA to hold flowback water from shale gas and oil shale production activities. The cost of disposing of this water varies between $\$ 12 \mathrm{~m}^{-3}$ to $\$ 125 \mathrm{~m}^{-3}$ (Boschee 2014). A newly 
fracked well may have consumed $>50,000 \mathrm{~m}^{-3}$ during the hydraulic fracturing process and reco-vered $25-50 \%$ of the water as flowback water over a 4-12 week period (Boschee 2012; Vengosh et al. 2014). The hypersaline flowback water composition is a function of location (e.g. Haluszczak et al. 2013). This water is typically transported to a processing site, prior to reinjection into a deep aquifer, or to reuse as a hydraulic fracturing fluid or discharge into the riparian environment (e.g. Boschee 2012).

Reactor 12A (Fig. 6) and 14 (Fig. 7) indicate that the rate of $\mathrm{NaCl}$ removal may increase with increa-sing feed water salinity. The desalination relationship established for Reactor 14 (Fig. 7i) can be used to provide an indication of the treatment times required for flowback water.

In the US Marcellus Shale, the salinity [IS] of the flowback water ranges from 6-142 $\mathrm{g} \mathrm{L}^{-1}$ (Fig. 8a). The $\mathrm{n}-\mathrm{Fe}^{0}$ will interact with each water composition to provide a different [BS]. The desalination relationship (Fig. 7i) allows estimation of the remediation time required to desalinate each flowback water in Fig. 8a to produce a product with an $\mathrm{EC}$ of $4.1 \mathrm{mScm}^{-1}$ (Fig. 8b). The $\mathrm{n}-\mathrm{Fe}^{0}$ treatment cost (Reactor 14) is competitive with existing flowback water treatment costs (e.g. Boschee 2014). The treatment cost indicated by Reactor 14 is $\mathrm{BP}=\$ 35 \mathrm{~m}^{-3} ; \mathrm{PCR}=\$ 1.35$ $10.18 \mathrm{~m}^{-3}$. Additional costs are impoundment and monitoring costs. The product water which is currently reinjected into deep aquifers for disposal could be used for agricultural purposes (e.g. livestock feed water (Curran 2007) or irrigation water (Ayers, Westcot 1985)).

Product water with an EC of $4.1 \mathrm{mScm}^{-1}$ is suitable for irrigation of barley, Bermuda grass, cotton, date palm, Harding grass, Sudan grass, sugar beet, rye grass, trefoil, wheat, wheat grass, without a loss of yield (e.g. Ayers, Westcot 1985). It can be used with some loss of yield for alfalfa, beets, broccoli, cantaloupe, corn, durum, fig, grape, meadow foxtail, olive, orchard grass, pomegranate, safflower, sesbania, sorghum, spinach, tomato (e.g. Ayers, Westcot 1985).

\section{Conclusions}

This study has established that placement of $n-\mathrm{Fe}^{0}$ powders into a saline water body (aquifer or impoundment) will result in its partial desalination. The effectiveness of the powders increases with decre-asing particle size, increasing feed water salinity and a nitrogen (or $\mathrm{N}_{2}$ $+\mathrm{H}_{2}$ ) pre-treatment. The $\mathrm{NaCl}$ is removed, together with other contaminants in the feed water. The powders have application for groundwater remediation by injection into an aquifer and remediation of impoundments by placement of the powders in water.
The desalination process (demonstrated by Reactors $9-11,13,14)$ only produces product water, requires no external energy source, requires no capital investment (assuming that the impoundments or injection wells exist). The associated costs include the acquisition cost of the ZVM, the costs of placing the ZVM in the reaction environment, the costs of reco-vering the product water and used ZVM.

The current remediation costs (demonstrated by Reactors 13,14$)$ are in the range $\$ 0.64-36 \mathrm{~m}^{-3}$ for the partial desalination of water, and $\$ 33-1450 \mathrm{~m}^{-3}$ for the production of potable water (as demonstrated by Reactors 9-12A). Reactor 12B has established that it may be possible to reduce the partial desalination treatment costs to less than $\$ 0.18 \mathrm{~m}^{-3}$. These costs indicate that the $\mathrm{n}-\mathrm{Fe}^{0}$ desalination process is cost competitive with existing technologies for the provision of emergency desalination, and for the removal of saline water held in impoundments.

Acknowledgements. This research was financed by DCA Consultants Ltd.

Bibliography

Al Hashemi R., Zarreen A., Al Raisi A., Al Marzooqi F.A., Hasan S.W., 2014, A review of desalination trends in Gulf Cooperation Council Countries, International Interdisciplinary Journal of Scientific Research, 1, 72-96

Al-Moubaraki A.H., Al-Judaibi A., Asiri M., 2015, Corrosion of $\mathrm{C}$-steel in the Red Sea: Effect of immersion time and inhibitor concentration, International Journal of Electrochemical Science, 10, 4252-4278

Antia D.D.J., 2010, Sustainable zero-valent metal (ZVM) water treatment associated with diffusion, infiltration, abstraction and recirculation, Sustainability, 2 (9), 2988-3073, DOI: 10.3390/su2092988

Antia D.D.J., 2014, Groundwater water remediation by static diffusion using nano-zero valent metals $[\mathrm{ZVM}]\left(\mathrm{Fe}^{0}, \mathrm{Cu}^{0}, \mathrm{Al}^{0}\right)$, $\mathrm{n}-\mathrm{FeH}^{\mathrm{n}+}, \mathrm{n}-\mathrm{Fe}(\mathrm{OH})_{\mathrm{x}}, \mathrm{n}-\mathrm{FeOOH}, \mathrm{n}-\mathrm{Fe}-\left[\mathrm{O}_{\mathrm{x}} \mathrm{H}_{\mathrm{y}}\right]^{(\mathrm{n}+/-)}$, [in:] Nanomaterials for Environmental Protection, B.I. Kharisov, O.V. Kharissova, H.V.R. Dias (eds.), Wiley Inc. Hoboken, New Jersey, USA, 3-25, DOI: 10.1002/9781118845530.ch1

Arumugam K., Varnado C.D., Sproules S., Lynch V.M., Bielawski C.W., 2013, Redox-switchable ring-closing metathesis: catalyst design, synthesis and study, Chemistry, 19 (33), 10866-10875, DOI: 10.1002/chem.201301247

Ayers R.S., Westcot D.W., 1985, Water quality for agriculture, Irrigation and Drainage Paper, No 29, Rev. 1, reprinted 1989, 1994, Food and Agriculture Organization of the UN, Rome

Balasubramanian P., 2013, A brief review on best available technologies for reject water (brine) management in indus- 
tries, International Journal of Environmental Sciences, 3 (6), 2010-2018, DOI: 10.6088/ijes.20130306000020

Boschee P., 2012, Handling produced water from hydraulic fracturing, Oil and Gas Facilities, 1, 22-26

Boschee P., 2014, Produced and flowback water recycling and reuse, Oil and Gas Facilities, 3, 16-24

Bottero J-Y., Manceau A., Villieras F., Techoubar D., 1994, Structure and formation of $\mathrm{FeOOH}(\mathrm{Cl})$ polymers, Langmuir, 10, 316-319, DOI: 10.1021/la00013a046

Butler E.L., 2012, Point of use water treatment with forward osmosis for emergency and population migration relief, Honors Scholar Theses, Paper 279, University of Connecticut

Butler E.L., Silva A., Horton K., Rom Z., Chwatko M., Havasov A., McCutcheon J.R., 2013, Point of use water treatment with forward osmosis for emergency relief, Desalination, 312, 23-30, DOI: 10.1016/j.desal.2012.12.013

Carberry J.J., 2001, Chemical and catalytic reaction engineering, Dover Publications, New York, 642 pp.

Charlet L., Tornassat C., 2005, Fe(II)-Na(I)-Ca(II) cation exchange on montmorillonite in chloride medium: evidence for preferential clay adsorption of chloride-metal ion pairs in seawater, Aquatic Geochemistry, 11, 115-137, DOI: 10.1007/ s10498-004-1166-5

Curran G., 2007, Water for livestock: interpreting water quality tests, Primefact No. 533, New South Wales Department of Primary Industry, State of New South Wales, Australia, available at http://www.dpi.nsw.gov.au/_data/assets/pdf_file/ 0018/111348/water-for-livestock-interpreting-water-qualitytests.pdf (data access 30.04.2015)

Dante S., Hou Z., Risbud S., Stroeve P., 1999, Nucleation of iron oxy-hydroxide nanoparticles by layer-by-layer polyionic assemblies, Langmuir, 15 (6), 2176-2182, DOI: 10.1021/ la980587j

Ebbing D.D., Gammon S.D., 1999, General Chemistry, $6^{\text {th }}$ edition, Houghton Mifflin Co, Boston, USA, 1101 pp.

Elimelech M., Phillip W.A., 2011, The future of seawater desalination: energy, technology and the environment, Science, 333 (6043), 712-717, DOI: 10.1126/science. 1200488

El-Nashar W.Y., 2013, The combined effect of water-logging and salinity on crop yield, IOSR Journal of Agriculture and Veterinary Science, 6 (4), 40-49, DOI: 10.9790/2380-0644049

EU, 1999, Council Directive 98/83/EC of $3^{\text {rd }}$ November 1998 on the quality of water intended for human consupmtion, Official Journal of the European Communities, L330, 32-51, available at http://eur-lex.europa.eu/LexUriServ/LexUriServ.do?uri=OJ:L:1998:330: 0032:0054:EN:PDF (data access 30.04.2015)

FAO, 2011, The state of the world's land and water resources for food and agriculture (SOLAW) - Managing systems at risk, Food and Agricultural Organization of the United Nations and Earth Scan, Abingdon, UK, available at http:// www.fao.org/docrep /015/i1688e/i1688e00.pdf (data access 30.04.2015)

Fronczyk J., Pawluk K., Michniak M., 2010, Application of permeable reactive barriers near roads for chloride ions removal, Annals of Warsaw University of Life Sciences: Land Reclamation, 42 (2), 249-259, DOI 10.2478/v10060-008-0083-5

Fronczyk J., Pawluk K., Garbulewski K., 2012, Multilayer PRBs - Effective technology for protection of the groundwater environment in traffic infrastructures, Chemical Engineering Transactions, 28, 67-72, DOI: 10.3303/CET1228012

German D., Thiex N., Wright C., 2008, Interpretation of water analysis for livestock suitability, C274, South Dakota State University and US Department of Agriculture, available at http://region8water.colostate.edu/PDFS/Interpretation $\% 20$ of $\% 20$ Water $\% 20$ Analysis $\% 20$ for\%20Livestock\%20Suitability.pdf (data access 30.04.2015)

Grattan S.R., 2002, Irrigation water salinity and crop production, Publication 8066, FWQP Reference Sheet 9.10, University of California, Oakland, California, USA, available at http:// region8water.colostate.edu/PDFS/Interpretation $\% 20$ of $\% 20$ Water\%20Analysis\%20for\%20Livestock\%20Suitability.pdf (data access 30.04.2015)

Hajbl F., Hamml H., M'nif A., 2010, Reuse of RO desalination plant reject brine, Journal of Phase Equilbria and Diffusion, 31 (4), 341-347, DOI: 10.1007/s11669-010-9727-3

Haluszczak L.O., Rose A.W., Kump L.R., 2013, Geochemical evaluation of flowback brine from Marcellus gas wells in Pennsylvania, USA, Applied Geochemistry, 28, 55-61, DOI: 10.1016/j.apgeochem.2012.10.002

Hill R., Koenig R.T., 1999, Water Salinity and crop yield, Utah Water Quality, AG-425.3, Utah State University Cooperative Extension, available at http://www.researchgate.net/ publication/242759516_WATER_SALINITY_AND_ CROP_YIELD/links/028f46510cf2dd0fc332cb55.pdf (data access 30.04.2015)

IS, 2012, Drinking Water Specification, Second Revision of IS 10500, Bureau of Indian Standards, New Delhi, India

Jardim W.F., 2014, Medicao e interpretacao de valores do potecial redox $\left(E_{H}\right)$ em matrizes ambientais, Quimica Nova, 37 (7), 1233-1235, DOI: 10.5935/0100-4042.20140207

Katerji N., van Hoorn J.W., Hamdy A., Mastrorilli M., 2003, Salinity effect on crop development and yield, analysis of salt tolerance according to several classification methods, Agricultural Water Management, 62 (1), 37-66, DOI: 10.1016/ S0378-3774(03)00005-2

Knapp K.C., Baerenklau K.A., 2006, Ground water quantity and quality management: agricultural production and aquifer salinization over long time scales, Journal of Agricultural and Resource Economics, 31 (3), 616-641

Kozin P.A., Boily J.-F., 2013, Proton binding and ion exchange at the akaganeite/water interface, Journal of Physical Chemis- 
try C, 117 (2), 6409-6419, DOI: 10.1021/jp3101046

McGeachy J., 2010, The progression of sequential reactions, Undergraduate Journal of Mathematical Modelling: One + Two, 2 (2), 1-17, DOI: 10.5038/2326-3652.2.2.5

Misstear B., Banks D., Clark L., 2006, Water wells and boreholes, Wiley Inc. Hoboken, New Jersey, USA, 513 pp.

Moganty S.S., Jayaprakash N., Nugent J.L., Shen J., Archer L.A., 2010, Ionic-liquid-tethered nanoparticles: hybrid electrolytes, Angewandte Chemie, 49 (48), 9158-9161, DOI: 10.1002/anie. 201004551

Muraoka M., Gillett S.L., Bell T.W., 2001, Redox-switchable materials, US Patent application US2005/0227071 A1, priority date 28 December 2001

Otte K., Schmahl W.W., Pentcheva R., 2012, Density functional theory study of water adsorption on FeOOH surface, Surface Science, 606 (21-22), 1623-1632, DOI: 10.1016/j.susc.2012.07.009

Pandey A., 2013, Environmental impacts of canal irrigation in India, Mediterranean Journal of Social Sciences, 4 (11), 138143, DOI: $10.5901 / \mathrm{mjas} .2013 . v 4 n 11 p 138$

Panta S., Flowers T., Lane P., Doyle R., Haros G., Shaala S., 2014, Halophyte agriculture: success stories, Environmental and Experimental Botany, 107, 71-83, DOI: 10.1016/j. envexpbot.2014.05.006

Perez F.R., Barrero C.A., Walker A.R.H., Garcia K.E., Nomura K., 2009, Effects of chloride concentration, immersion time and steel composition on the spinel phase formation, Materials Chemistry and Physics, 117 (1), 214-223, DOI: 10.1016/j.matchemphys.2009.05.045

Pourbaix M., 1974, Atlas of electrochemical equilibria in aqueous solutions, NACE International, Cebelcor, USA, 664 pp.

Rahil M., Hajjeh H., Qanadillo A., 2013, Effect of saline water application through different irrigation intervals on tomato yield and soil properties, Open Journal of Soil Science, 3 (3), 143-147, DOI: 10.4236/ojss.2013.33016

Raluy R.G., Serra L., Uche J., Valero A., 2004, Life-cycle assessment of desalination technologies integrated with energy production systems, Desalination, 167, 445-458, DOI: 10.1016/j.desal.2004.06.160

Rasel H.H., Hasan M.R., Ahmed B., Miah M.S.U., 2013, Investigation of soil and water salinity, its effect on crop production and adaptation strategy, International Journal of Water Resources and Environmental Engineering, 5 (8), 475-481, DOI: $10.5897 /$ ijwree2013.0400

Ruby C., Aissa R., Gehin A., Cortot J., Adelmoula M., Genin J.-M., 2006, Green rusts synthesis by coprecipitation of Fe ${ }^{\text {II }}$ $\mathrm{Fe}^{\mathrm{III}}$ ions and mass balance diagram, Comptes Rendus Geoscience, 338 (6-7), 420-432, DOI: 10.1016/j.crte.2006.04.008

Savoie J.G., Kent D.B., Smith R.L., LeBlanc D.R., Hubble D.W., 2004, Changes in ground-water quality near two granular iron permeable reactive barriers in a sand and gravel aquifer, Cape Cod, Massachusetts, 1997-2000, Water-Resources In- vestigation Report 03-4309, US Geological Survey, Reston, Virginia, USA, 77 pp., available at http://pubs.usgs.gov/wri/ wri034309/pdf/wrir034309.pdf (data access 30.04.2015)

Shimakoshi H., Shibata K., Hisaeda Y., 2009, Molecular recognition of redox switchable bis crown moieties assembled on a dicobalt complex, Inorganic Chemistry, 48 (3), 1045-1052

Sorokina I.D., Dresvyannikov A.F., 2014, Synthesis and study of new complex iron-aluminium reagent for water treatment, Acta Metallomica-MEEMB, 11 (1), 23-34,

Sorour M., Hani H.A., Shaalan H.F., Al-Bazedi G.A., 2014, Preliminary techno-economics assessment of developed desalination/salt recovery facility based on membrane and thermal techniques, Desalination and Water Treatment, DOI: 10.1080/19443994.2014.94775

Tang Z., Hong S., Xiao W., Taylor J., 2006, Characteristics of iron corrosion scales under blending of ground, surface and saline waters and their impact on iron release in the pipe distribution system, Corrosion Science, 48 (2), 322-342, DOI: 10.1016/j.corsci.2005.02.005

Varnado C.D., Rosen E.L., Collins M.S., Lynch V.M., Bielawski C.W., 2013, Synthesis and study of olephin metathesis catalysts supported by redox switchable diaminocarbene[3] ferocenophanes, Dalton Transactions, 42 (36), 13251-13264, DOI: $10.1039 / \mathrm{c} 3 \mathrm{~d} t 51278 \mathrm{a}$

Vengosh A., Jackson R.B., Warner N., Darrah T.H., Kondash A., 2014, A critical review of the risks to water resources from unconventional shale gas development and hydraulic fracturing in the United States, Environmental Science \& Technology, 48 (15), 8334-8348, DOI: 10.1021/es405118y

Venkatesan R., 2014, Comparison between LTTD and RO process of sea-water desalination: an integrated economic, environmental and ecological framework, Current Science, 106 (10), 378-386

Warner N.R., Christie C.A., Jackson R.B., Vengosh A., 2013, Impacts of shale gas wastewater disposal on water quality in Western Pennsylvania, Environmental Science \& Technology, 47 (20), 11849-11857, DOI: 10.1021/es402165b

WHO, 2006, Guidelines for Drinking Water Quality, World Health Organisation, Geneva, Switzerland, 564 pp., available at http://whqlibdoc.who.int/publications/2011/97892415 48151_eng.pdf (data access 30.04.2015)

WHO, 2011, How much water is needed in emergencies, Technical Notes on Drinking Water, Sanitation and Hygiene in Emergencies, No. 9, World Health Organisation, Geneva, available at http://www.who.int/ water_sanitation_health/publications/2011/tn9_how_ much_water_en.pdf (data access 30.04.2015)

Wilkin R.T., McNeil M.S., 2003, Laboratory evaluation of zero-valent iron to treat water impacted by acid mine drainage, Chemosphere, 53 (7), 715-725, DOI: 1016/S00456535(03)00512-5 
Wilkin R.T., Puls R.W., Sewell G.W., 2003, Long-term performance of permeable reactive barriers using zero-valent iron: geochemical and microbiological effects. Ground Water, 41 (4), 493-503, DOI: 10.1111/j.1745-6584.2003.tb02383.x

Younos T., Tulou K.E., 2005, Overview of desalination technologies, Journal of Contemporary Water Research \& Education, 132 (1), 3-10, DOI: 10.1111/j.1936-704X.2005. mp132001002.x

Yu X., Liao Y., Oladipo I.O., 2014, Effect of salinity water irrigation on maize growth in northwest region, Journal of Chemical and Pharmaceutical Research, 6 (1), 300-305

Yue J., Jiang X., Yu A., 2011, Experimental and theoretical study on the beta-FeOOH nanorods: growth and conversion, Journal of Nanoparticle Research, 13, 3961-3974, DOI: 10.1007/ s11051-011-0320-4
Yurtseven E., Ozturk H.S., Avci S., 2014, Mass balance criteria in soil salinity management: different irrigation water qualities and leaching ratio, Journal of Agricultural Science, 20 (2), 103-111, DOI: 10.15832/tbd.91886

Zekri S., Al-Maktoumi A.K., Abdalla O.A.E., Akil J., Charabi Y., 2014, Hydrological and economical simulations: emergency water supply for Muscat, Water Policy, 16, 340-357, DOI: $0.2166 /$ wp. 2013.187

Zotalis K., Dialynas E.G., Mamassis N., Angelakis A.N., 2014, Desalination technologies: Hellenic Experience, Water, 6 (5), 1134-1150, DOI: 10.3390/w6051134 